May 1985

\title{
A FISHERIES EVALUATION OF THE SUNNYSIDE CANAL FISH SCREENING FACILITY, SPRING 1985
}

Annual Report 1985

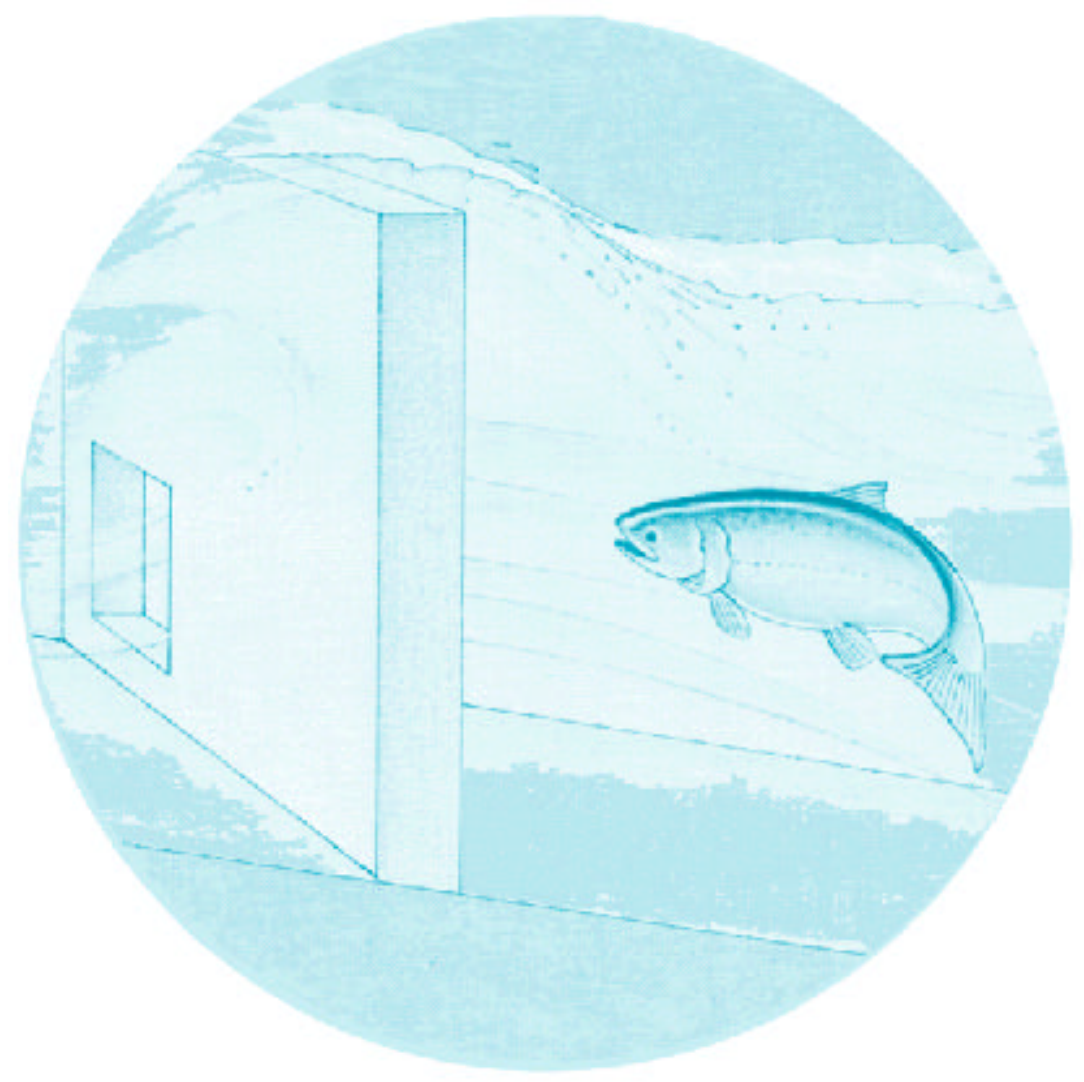

DOE/BP-01830-1 
This report was funded by the Bonneville Power Administration (BPA), U.S. Department of Energy, as part of BPA's program to protect, mitigate, and enhance fish and wildlife affected by the development and operation of hydroelectric facilities on the Columbia River and its tributaries. The views of this report are the author's and do $\mathrm{r}$ necessarily represent the views of BPA.

This document should be cited as follows:

Neittel,D. A.; C. S. Abernethy, E. W. Lusty, L. A. Prohammer, Pacific Northwest Laboratory, U. S. Department of Energy, Bonneville Power Administration, Division of Fish and Wildlife, Contract No. DEAC06-RL01830, 48 electronic pages (BPA Report DOE/BP-01830-1)

This report and other BPA Fish and Wildlife Publications are available on the Internet at: http://www.efw.bpa.gov/cgi-bin/efw/FW/publications.cgi

For other information on electronic documents or other printed media, contact or write to:

Bonneville Power Administration

Environment, Fish and Wildlife Division

P.O. Box 3621

905 N.E. 11th Avenue

Portland, OR 97208-3621

Please include title, author, and DOE/BP number in the request. 


\title{
A FISHERIES EVALUATION OF THE SUNNYSIDE CANAL FISH SCREENING FACILITY, SPRING 1985
}

\author{
Annual Report
}

\author{
Prepared by: \\ D. A. Neittel \\ C. S. Abernethy \\ E. W. Lusty \\ L. A. Prohammer \\ Pacific Northwest Laboratory
}

\author{
Prepared for: \\ U.S. Department of Energy \\ Bonneville Power Administration \\ Environment, Fish and Wildlife \\ PO Box 3621 \\ Portland, Oregon 97208 \\ Contract No. DEAC06-RL01830
}

December 1985 


\section{CONIENTS}

10. 8

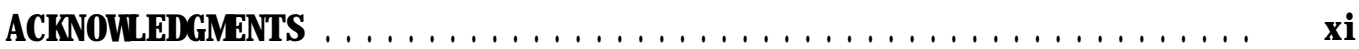

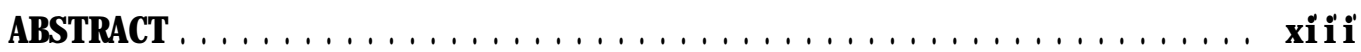

GoSSARY $\ldots \ldots \ldots \ldots \ldots \ldots \ldots \ldots \ldots \ldots \ldots \ldots \ldots \ldots \ldots \ldots \ldots \ldots$

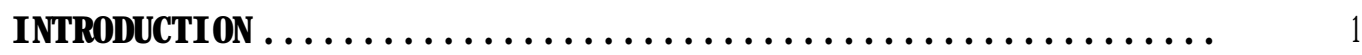

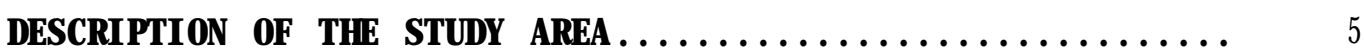

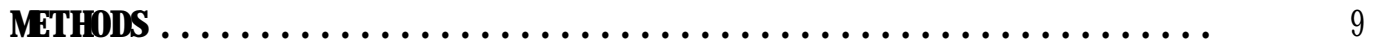

TEST FISH $\ldots \ldots \ldots \ldots \ldots \ldots \ldots \ldots \ldots \ldots \ldots \ldots \ldots \ldots \ldots \ldots \ldots$

Steel head $\ldots \ldots \ldots \ldots \ldots \ldots \ldots \ldots \ldots \ldots \ldots \ldots \ldots \ldots \ldots, 9$

Chi nook Sal mon ....................... 9

SAMPLI NG EQU PMENT $\ldots \ldots \ldots \ldots \ldots \ldots \ldots \ldots \ldots$

Inclined $\mathbf{P l}$ ane $\ldots \ldots \ldots \ldots \ldots \ldots \ldots \ldots \ldots \ldots \ldots \ldots$

Fyke Net $\ldots \ldots \ldots \ldots \ldots \ldots \ldots \ldots \ldots \ldots \ldots \ldots \ldots \ldots \ldots$

Hol di ng Facilities.................... 10

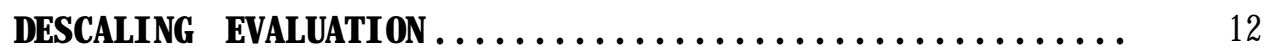

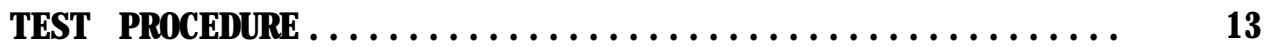

Fi sh Transport and Rel ease $\ldots \ldots \ldots \ldots \ldots \ldots \ldots \ldots, 13$

Fi sh Rel ease Locations ................... 13

Rel ease Control s....................... 14

Fi sh Capt ure and Eval uati on ................ 14

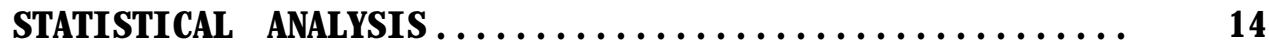

RESULTS AND DI SCUSSI ON. . . . . . . . . . . . . . . . . . . . . . . . 15

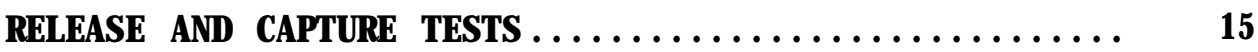

Pri mary Fi sh Return Pi pe................ 15 
Intermediate Bypass Ent rance $\ldots \ldots \ldots \ldots$

Termi nal Bypass Entrance $\ldots \ldots \ldots \ldots \ldots \ldots$

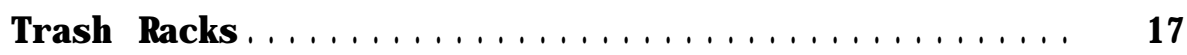

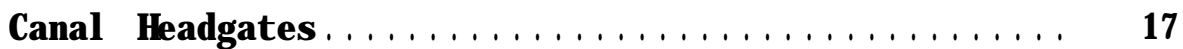

DESCALI NG OF HATCHERY- RELEASED AND NATIVE FISH.......... 18

FI SH PASSAGE TIME THROGH THE SCREENING FACILITY........ 19

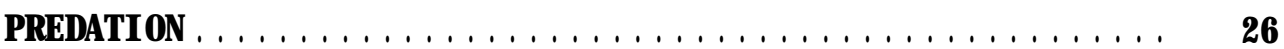

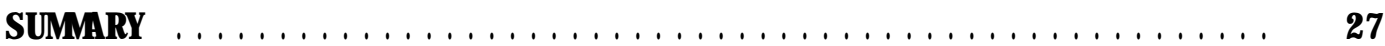

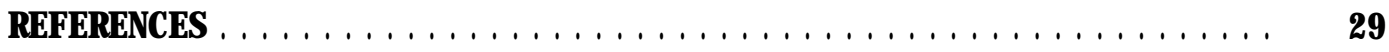

APPEND X A - CRI TER A USED TO EVALUATE DESCALING OF

FISH AT SUNYYSI DE CANAL FI SH SCREEN NG FACILITY,

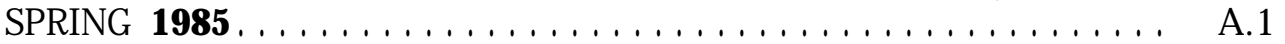

APPENDIX B - RELEASE AND CAPTURE DATA FROM THE

SUNYSI DE CANAL FISH SCREENING FACILITY

EVALUATI ON, SPRI NG $1985 \ldots \ldots \ldots \ldots \ldots \ldots \ldots \ldots \ldots$.1 


\section{FIGURES}

1 Map of Yakima River Basin Showing Locations of Sunnyside Diversion Dam and Other Fish Protection and Passage Facilities.........................

2 Aerial View of the Sunnyside Dam and Sunnyside Canal

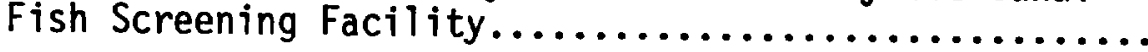

3 Aerial View of the Flow Control Structure and Fish Bypass System in the Sunnyside Canal Fish Screening Facility.

4 Approach and Sweeping Velocity Vectors Across Wire Mesh Screens

5 Inclined Plane System Used at Sunnyside Canal Fish Screening Facility, Spring 1985.

6 Fyke Net Used at the Sunnyside Canal Fish Screening

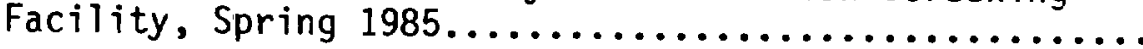

7 Division of Body Areas to Evaluate Scale Loss on Salmonids at Sunnyside Canal Fish Screening Facility,

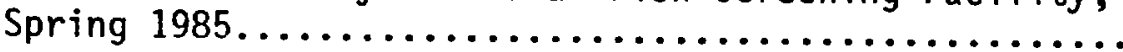

8 Timing of Capture for Steelhead, Salmo gairdneri, Released Downstream of Canal Headgates at Sunnyside Canal Fish Screening Facility, Spring 1985

9 Timing of Capture for Steelhead, Salmo gairdneri, Released Downstream of the Trash Racks at Sunnyside Canal Fish Screening Facility, Spring 1985...........

10 Timing of Capture for Chinook Salmon, Oncorhychus tshawytscha, Released Downstream of the Canal Headgates at the Sunnyside Canal Fish Screening Facility, Spring 1985

11 Timing of Capture for Chinook Salmon, Oncorhynchus tshawytscha, Released Downstream of the Trash Rack at Sunnyside Canal Fish Screening Facility, Spring 1985...

12 Catch Per Unit Effort for Chinook Salmon, Oncorhychus tshawytscha, as A) Number of Fish Captured in Each Sample and B) as a Percent of the Released Fish that Were Remaining to be Captured (Canal Headgates Test June 11,1985 ) 
13 Catch Per Unit Effort for Chi nook Sal mon, Oncornynchus tshawytscha, as A) Number of Fi sh Capt ured in Each Sample and B) as a Percent of the Rel eased Fi sh that Were Remaining to be Capt ured (Canal Headgates Test

June 19, 1985).

14 Catch Per Unit Effort for Chi nook Sal mon, Oncorhyñ̄inüs tshawytscha, as A) Number of Fi sh Capt ure in Each Sample and B) as a Percent of the Rel eased Fi sh that Were Renai ni ng to be Captured (Trash Rack Test, Spri ng 1985)

A.1 Descal ing Eval uati on Data Sheet Used at the Sunnysi de

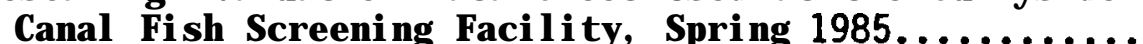

A 2 Letter From Steve Pettit, I daho Fi sh and Game, Descri bi ng the 1985 Mdi fi cations to the Scal e Loss Eval uati on Criteri $a_{1} \ldots \ldots \ldots \ldots \ldots \ldots \ldots \ldots \ldots$ 


\section{TABLES}

1 Descaling and Mortality Data from Release and Capture Tests with Chinook Salmon, Oncorhynchus tshawytscha, Smolts at the Sunnyside Canal Fish Screening Facitity,

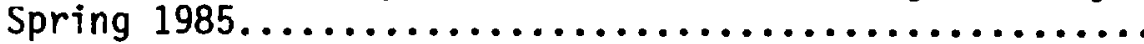

2 Descaling and Mortality Data from Release and Capture Tests with Steelhead, Salmo gairdneri, Smolts at the Sunnyside Canal Fish Screening Facility, Spring 1985...

3 Scale Loss for Hatchery-Released and Native Fish Captured during Tests at the Sunnyside Canal Fish

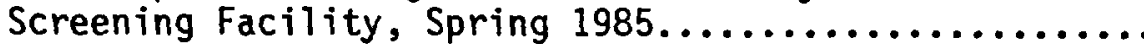

B.1 Percentage of Steelhead, Salmo gairdneri, Descaled or Killed in each Test at the Sunnyside Canal Fish

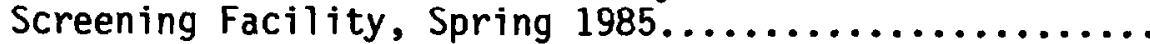

B.2 Percentage of Chinook Salmon, Oncorhynchus tshawytscha, Descaled or Killed in each Test at the Sunnyside Canal

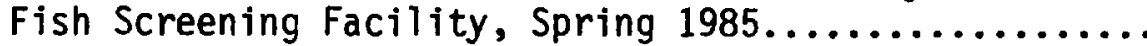


The Bonnevi I l e Power Admi ni strati on (BPA) and the Bur eau of Recl anation (BR) are provi ding funding to construct fi sh passage and protective facilities at 20 i rrigation di versions in the Yaki ma Ri ver Basi $n$, Wishi ngt on. Constructi on i mpl enents secti on 904 (d) of the Nort hwest Power PI anni ng Counci I' $s$ Col unbi a Ri ver Basi n Fi sh and Vill dl ife Program (NPPC 1984) whi ch addresses nat ural propagation of sal mon to hel $p$ mitigate fish and wild ife l osses caused by hydroel ectric devel opnent throughout the Col unbi a Ri ver Basi $\mathbf{n}$.

The Sunnysi de Canal Fi sh Screening Facility (Sunnysi de Screens) is one of the protective facilities built by BPA. The screening facility di verts fish from the Sunnyside Canal back into the Yaki $\mathrm{ma}$ River. Thi s report di scusses results of a fi sheries eval uati on of the Sunnysi de Screens. Studi es were conducted where fi sh were pl aced upstream of or withi $n$ the Sunnysi de Screens and capt ured bef ore they entered the river. Results i ndi cate that fish are safely diverted by the facility from the canal to the ri ver.

The study emphasi zed sal noni ds, and onl y steel head, Sal no gai rdneri, and spring chi nook sal mon snol ts were tested. ve di d not test smaller zero-age fal I chi nook sal non, oncorhynchus tshawytscha, whi ch may al so pass through the sunnyside Fish Screening Facility. Testing was I i mited to conditions near ful I fl ow capacity for the canal. 


\section{ACKNONLEDGENTS}

The i nvol vement and cooperation of many peopl e hel ped this project succeed. Tom Cl une of the Bonneville Power Administration was the Proj ect Manager. Bob Tuck and Larry Wisserman of the Yaki m I ndi an Nati on, Gary Mal $m$ of the U. S. Fi sh and Vil dl i fe Servi ce, John Easterbrooks of the Whshi ngt on State Department of Fi sheri es, Ron Eggers of the Northuest Power PI anni ng Council, and Bob Vereel and of the Nati onal Mari ne Fi sheri es Servi ce provided i mport ant consul tati on during devel opment of the st udy pl an. Bi II Whis sdorf and Ral ph Mal son of the Leavenuorth Hatchery hel ped with the procurement and hol di ng of chi nook sal mon. Herman Sti I water of the Northuest Steel head and Sal mon Council and J oe Steel e of the Whishingt on State Department of Gane hel ped with the procurement and hol di ng of steel head. Steve Pettit of the I daho Department of Fi sh and Gane and Ji m Athearn of the U.S. Corps of Engi neers provi ded i nf or mation and training tools for the descal ing eval uati ons.

The manuscri pt was revi ewed by Carol ynn Novich, Denni s Dauble, and Bob Gray. Bi II Hanf and $\mathbf{A}$ Scott assi sted with the fi eld tests. Joan Segna and Gai I Pool e typed the manuscript. 
The Sunnyside Canal Fish Screening Facility (Sunnyside Screens) is part of a joint project by the Bonneville Power Administration and the Bureau of Reclamation to Construct Fish passage and protective facilities at existing irrigation diversions in the Yakima River Basin. The project is part of the Northwest Power Planning Council's (NPPC) Columbia River Basin Fish and Wildlife Program. The construction implements Section 904 (d) of the NPPC plan which addresses natural propagation of salmon.

This is the first annual report for the fisheries evaluation of the diversion screens. This report summaries the evaluation of the work conducted at the Sunnyside Screens. About 4000 chiriook salmon, Oncorhyncus tshawytscha, and 2000 steelhead, Salmo gairdneri, smolts were released in front of or within the Sunnyside Canal Fish Screening Facility. We caught 3625 chinook salmon and less than $2 \%$ were descaled or dead. We captured 507 of the steelhead and none were descaled or dead.

The Sunnyside Screens are in the Sunnyside Canal, about $360 \mathrm{~m}$ downstream of the Sunnyside Dam on the Yakima River (river kilometer 167). The screening facility diverts fish that have entered the canal back into the Yakima River. Descaling and mortality data were gathered by releasing branded fish into the canal, upstream of the facility, and capturing them before they returned to the river. Captured fish were anesthetized and examined for descaling that occurred during passage through the screening facility. The methods used for this evaluation were reviewed by the Washington State Department of Fisheries, U. S. Fish and Wildlife Service, National Marine Fisheries Service, Northwest Power Planning Council, and the Yakima Indian Nation. 


\section{GOSSARY}

Approach vel oci ty

Canal headgates

Fi sh bypass system

Fi sh return pumps

Fi sh return water

Fl ow control structure

I nternedi ate bypass entrance

Inter medi ate bypass

Internedi ate bypass pi pe

Li ve- box the rate at which water noves perpendicul ar through the face of a screen

structure that control s the vol une of river water that is di verted from the dam reservoi $r$ into the i rrigati on canal

that portion of the fish screening facility that collects fish noving al ong the screen and di verts them back to the river

t no pumps on the separati on chanber that pump fish return vater from the separati on chanber to the canal

water di verted through the screen facility into the secondary separati on chamber and subsequently back into the river or into the fish return pumps

that portion of the fish screening facility that regulates the vel ocity of the water through the fish bypass system

the opening midway in the screening structure that di verts about hal $f$ the fish bypass water into the di versi on

angl ed concrete wal I that gui des fi sh gui dance wal I and uater into the internedi ate bypass entrance

steel pi pe that carries uater and fi sh from the internedi ate bypass entrance to the separation chanber

a contai ner desi gned to hol d I i ve fi sh for an extended peri od of ti me 
Pri mary fish return pi pe

Rotary screens

Screen structure

Secondary fish return pi pe

Separati on chamber

Separati on screens

Snol t

Sweepi ng vel oci ty

Terminal bypass entrance

Trash rack pi pe that ret urns water and fi sh from the separation chamber to the ri ver

cyl i ndri cal wi re mesh structures used to filter fish and debris from water entering the canal

the concrete struct ure that supports the rotary drum screens, and the fi sh bypass system

auxi I i ary pi pe to suppl ement ret urn of water and fish to the river when fi shwater return pumps are not norking at ful I capacity

open chamber at the terminus of the screen struct ure where $80 \%$ of the di versi on water is ret urned to the canal and $20 \%$ of the di versi on water and $100 \%$ of the $f i$ sh are returned to the river

vertical traveling screens that prevent fish from being pumped from the separati on chanber i nto the canal by the fi shwater return pumps

a salmonid I ifestage in whi ch the fi sh undergo physi ol ogi cal and behavi oral changes and begi $n$ outmigrating from freshuater to the ocean

rate at which water noves paral lel to the face of a screen

vertical sl ot passageway that carries or di rects uater from the terminus of the screen structure i nto the separation chanber

rack upstream of the fish screen structure to col lect debris in the water and protect the screens 


\section{INTRODUCTION}

The Yakima River Basin has historically supported a significant salmonid fishery. During the late 1800 s, between 500,000 and 600,000 adult salmon, Oncorhynchus spp., and steelhead, Salmo gairdneri, returned to the Yakima River and its tributaries (Bureau of Reclamation 1984). There were runs of spring, summer, and fall chinook salmon, $\underline{0}$. tshawytscha, coho salmon, $\underline{0}$. kisutch, sockeye salmon, $\underline{0}$. nerka, and steelhead.

Some of the runs are extinct or near extinction. Present spawning escapement averages about 2000 salmonids (Bureau of Reclamation 1984). There are no sockeye salmon migrating into the Yakima River Basin and in 1983 only 37 coho salmon passed the Prosser Diversion Dam (Hollowed 1984).

The decline in Yakima River Basin runs is the result of many factors. Spawning and rearing habitat has been reduced by construction and operation of diversion dams. Stream flow for fish has been inadequate because of conflicts with other water uses. Ineffective fish passage facilities for adults and juveniles at diversion dams have resulted in reduced survival during migration. Additionally, many Yakima River fish are killed while passing dams on the Columbia River.

The Pacific Northwest Electric Power Planning and Conservation Act (Public Law 96-501) was passed to prepare a regional Conservation and Electric Power Plan. The Northwest Power Planning Council administers the plan and is charged with developing a program to protect and enhance fish and wildlife and mitigate the effects of the development, operation, and management of hydroelectric facilities.

The Yakima River Basin was selected as a site for enhancement of salmon and steelhead runs in the Pacific Northwest. The Bonneville Power Administration (BPA) and the Bureau of Reclamation (BR) are funding the construction of fish passage and protection facilities at 20 existing irrigation diversions in the Yakima River Basin (Figure 1). BPA is also providing funds to the Yakima Indian Nation to develop methods to increase production of spring chinook salmon in the Yakima River Basin.

The Sunnyside Diversion Dam and Canal are part of the passage and protection facilities being constructed by BPA and BR. Construction of diversion screens in the canal was completed in the spring of 1985. Subsequently, BPA asked the Pacific Northwest Laboratory (PNL) to evaluate screen effectiveness in diverting 


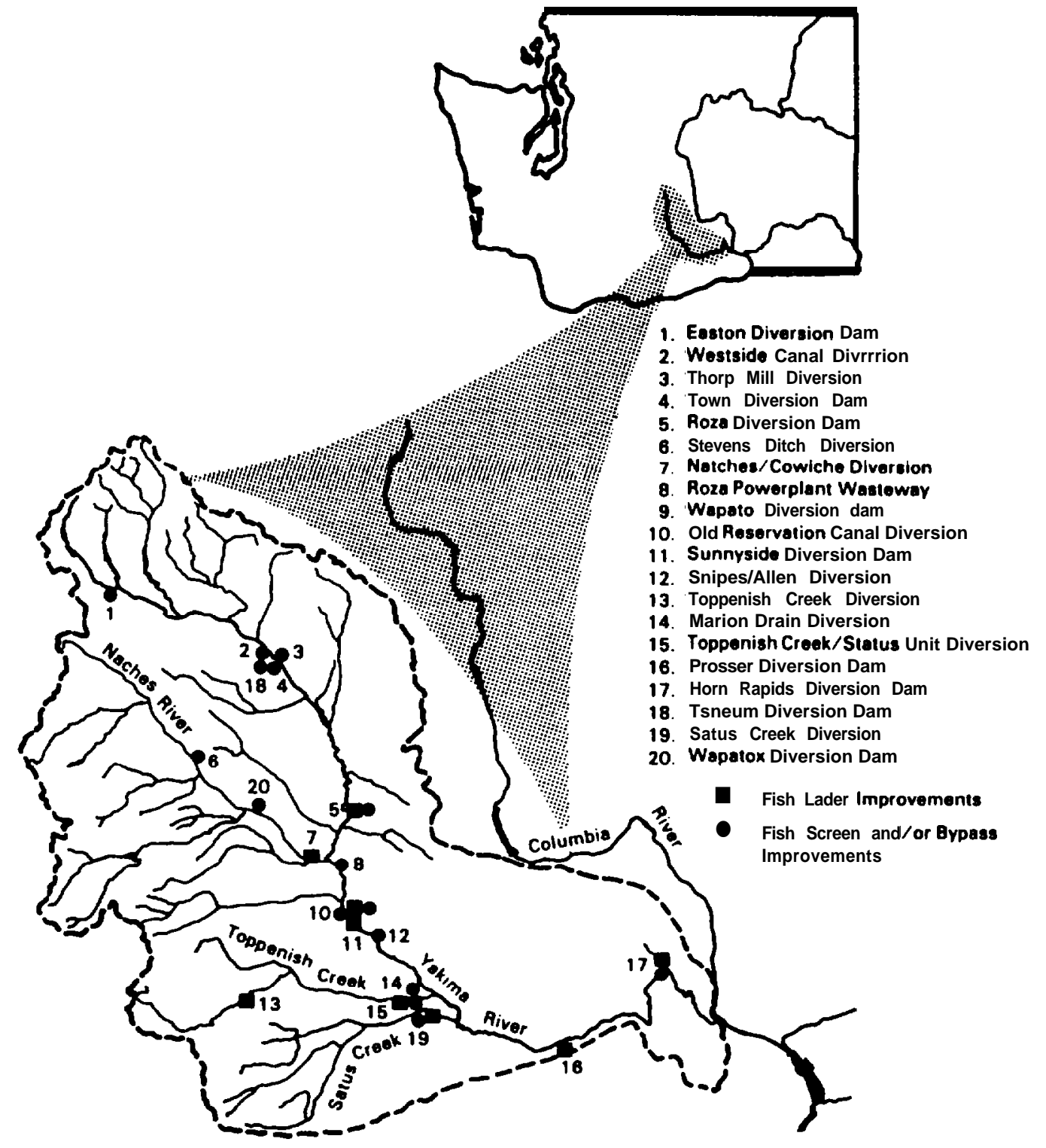

FI GRE 1. Map of Yakf na Ri ver Basi $n$ I ncl udi ng Locati ons of the Sunnysi de Di versi on Dam and Other Fi sh Protection and Passage Facilities 
fi sh that had entered the Sunnysi de Canal Dam back i nto the Yaki ma Ri ver. The Sunnysi de Canal di verts up to $75 \%$ of the water from the Sunnysi de Dam Reservoi $r$.

Thi s report describes work that PN fi sheries staff conducted at the Sunnysi de Screens in 1985 . The report describes the screening facility, methods used to eval uate the screens effecti veness, and the resul ts of our studi es. 


\section{DESCR PTI ON OF THE STUDY AREA}

The Sunnysi de Di versi on Dam and Canal are I ocated on the Yaki $\mathrm{ma}$ Ri ver at $\mathbf{r i}$ ver ki l oneter 167. The dam creates a reservoi $r$ in the Yaki ma Ri ver from which uater is di verted i nto the Sunnysi de Canal. Canal fl ow vari es from 17 cubi c meters/second $\left(\mathrm{m}^{3} / \mathrm{sec}\right)$ to $37 \mathrm{~m}^{3} / \mathrm{sec}$ duri ng the i rrigation season. Canal fl ow begi ns each year in I ate March or early April with the opening of the canal headgates (Figure 2). Canal fl ous are l onest in the spring and usual I y peak in July. Fl ous renai $n$ near naxi mum unt i I I ate sumer, when i rrigati on denand is reduced. The canal is empti ed i n Oct ober.

The Sunnysi de Canal Fi sh Screening Facility (Sunnysi de Screens) is I ocated about $360 \mathrm{~m}$ downstream of the Sunnysi de Canal

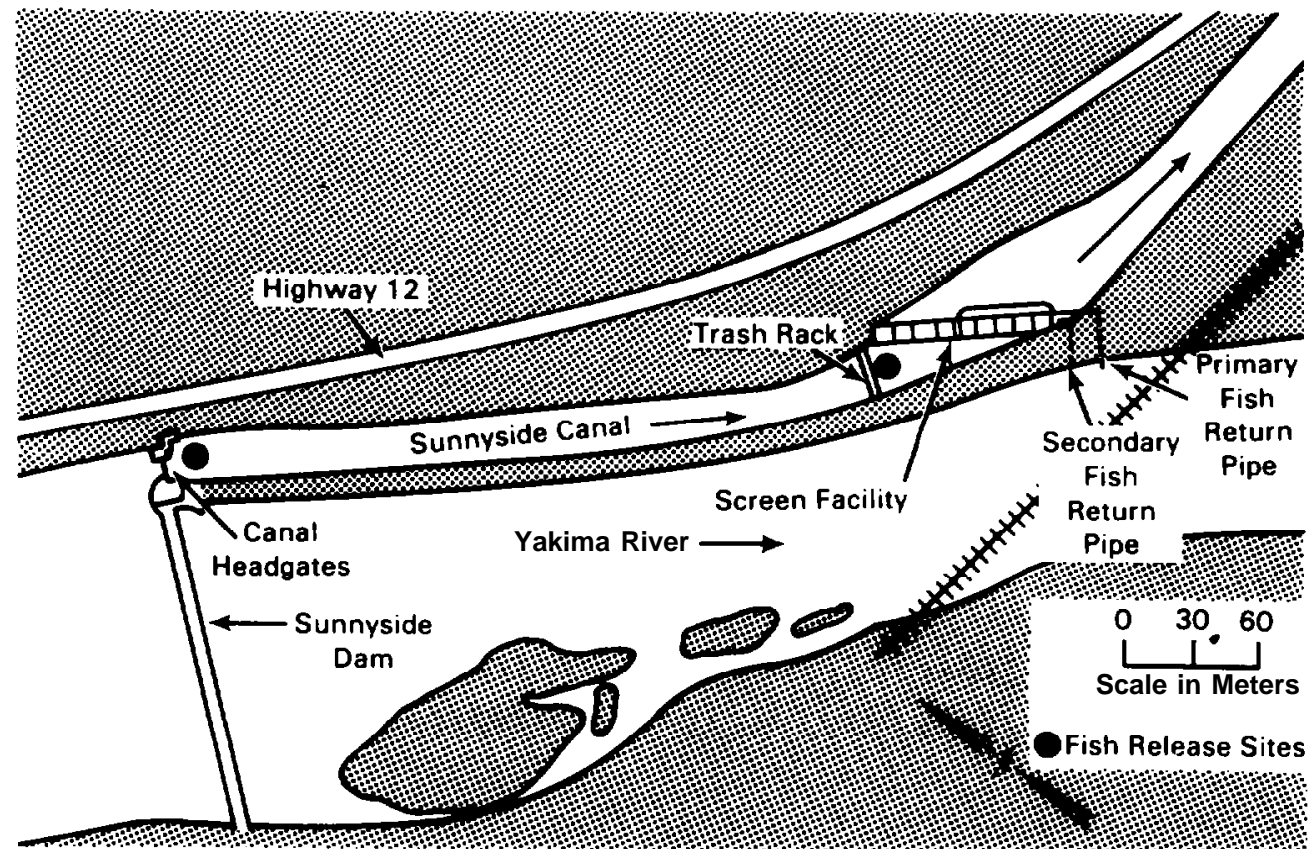

FI GRE 2. Aeri al Vi ew of the Sunnysi de Dam and Sunnysi de Canal Fi sh Screening Facility 
headgates. The screening facility prevents fish that are di verted into the canal from renai ning in the canal and safel $y$ di rects them back into the Yaki ma Ri ver.

A trash rack has been $\mathrm{pl}$ aced i $\mathrm{n}$ the canal upstream of the screening facility (Figures 2 and 3) to "filter" out large debris that is di verted into the canal. The rack prevents I arge logs or tree branches from damaging the screens or interfering with the fl ow control through the screening facility.

The screening facility is made of concrete and houses 17 cyl i ndri cal screens (Figure 3) whose axes are paral lel to the l ength of the structure. Each screen is about $3.5 \mathrm{~m}$ wi de and 7. $5 \mathrm{~m}$ in di aneter. Whter depth at the screens varies with canal fl ow However, the average depth across the face of the screens is about $6.0 \mathrm{~m}$

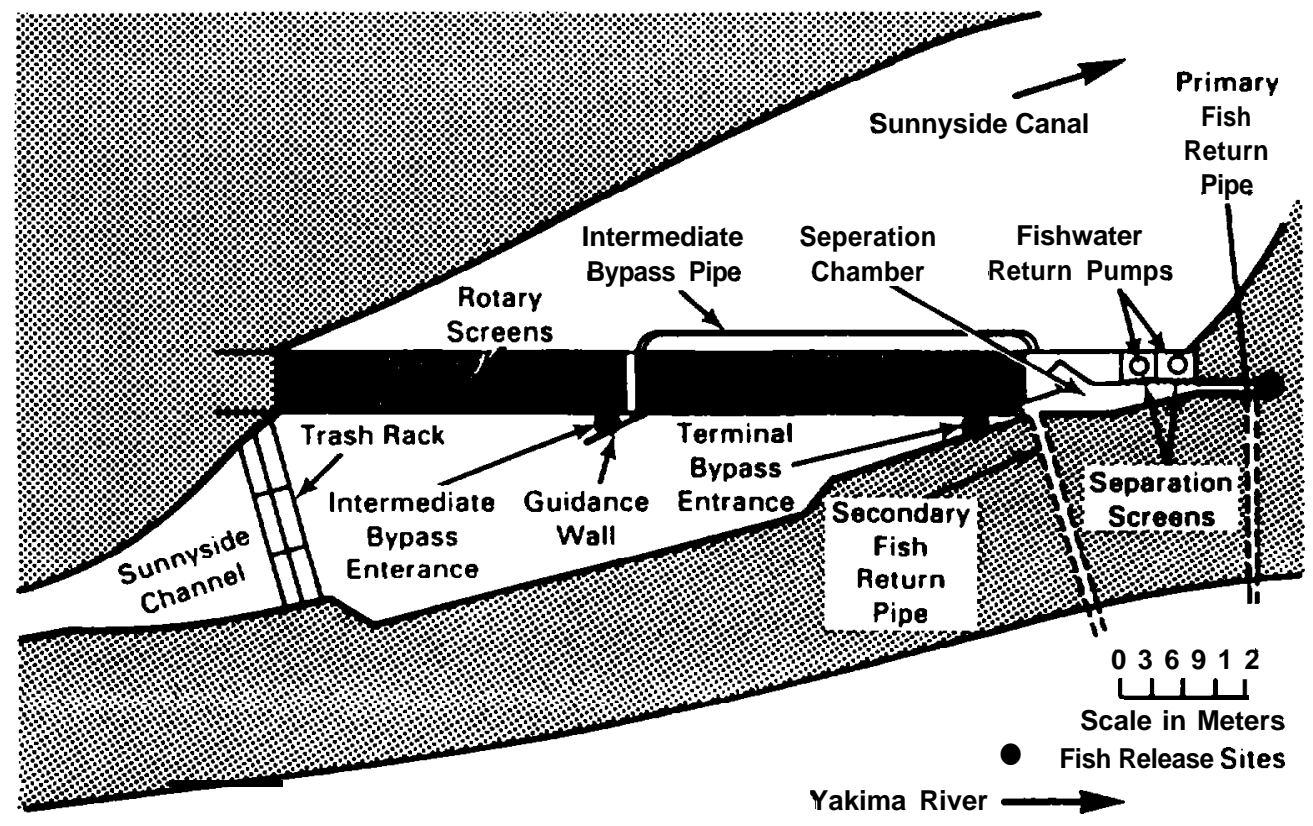

FI GRE 3. Aeri al Vi ew of the Fl ow Control Structure and Fi sh Bypass System in the Sunnysi de Canal Fish Screening Facility 
The screening facility al so has a fl ow control structure and a separati on chamber at the downst ream end (Fi gure 3). Wht er and fi sh that are di verted past the front of the screens, toward the pri mary fi sh return pi pe, pass through the fl ow cont rol struct ure and separati on chamber. Duri ng nor nal operati on, about $2.8 \mathrm{~m}^{3} / \mathrm{sec}$ of water and al I fish are di verted i nto the separation chanber. Two fi shwater return pumps are I ocated near the terminus of the separation chanber. About $80 \%$ of the water entering the separati on chamber is pumped i nt o the canal. Travel ing screens posi ti oned between the pump i ntakes and the separation chamber prevent fish and debris from bei ng entrai ned in the pumpback system The fi sh and water, not pumped back into the canal, are di rected back into the Yaki na Rer vi a the primary fish return pi pe.

The screening facility is oriented in the canal at a 26- degree angl e to the canal fl ow Thi s ori ent ati on provi des a differential between the approach vel ocity and the sweeping vel ocity at the screen. Approach vel ocity is that component of the uater vel ocity perpendi cul ar to the face of the screen (East erbrooks 1984, Fi gure 4). Sweeping vel oci ty is that component of the water vel ocity parallel to the screen face (Figure 4). During normal operation, the approach vel ocity is I ess than $0.014 \mathrm{~m}^{3} / \mathrm{sec}$ and the sweepi ng vel oci ty is great er than $0.057 \mathrm{~m}^{3} / \mathrm{sec}$. Thi s vel ocity di fferential was incorporated i nto the screen design so fish will not be i mpi nged on the screens, but wil I be safel y gui ded into the fl ow control struct ure and back i nto the Yaki na Ri ver.

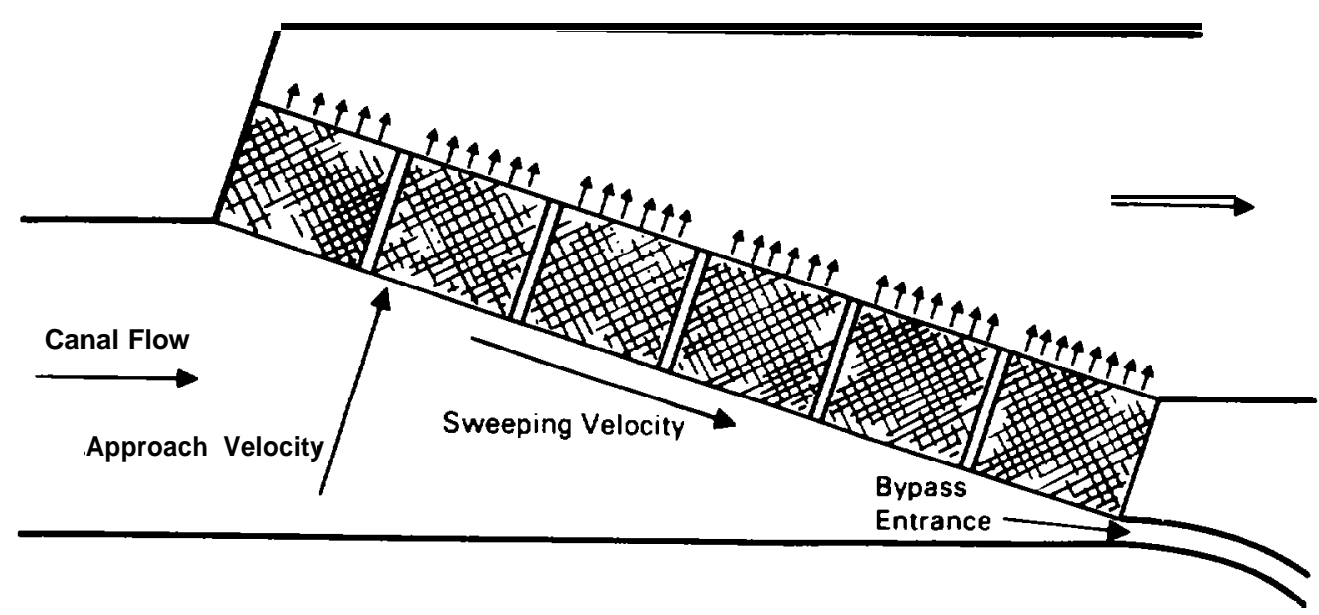

FI GRE 4. Approach and Sweeping Vel oci ty Vectors Across V're Mesh Screens 


\section{METHODS}

St udi es were conducted where fi sh were rel eased upst ream of the facility and capt ured at the terminus of the fl ow control structure or the pri mary fish return pi pe. The fi sh were eval uated for scal e I oss after capt ure. Sone fi sh were hel d for posttest observation.

\section{TEST FI SH}

Sal moni d snol ts, hat ched and reared upst ream of Sunnysi de Dam migrate downst ream each year begi nning in early spring and conti nui ng through mid sumer. Addi ti onally, many snol ts are rel eased upstream of Sunnysi de Dam as part of Yaki ma Ri ver Basi n sal noni d enhancement proj ects. Snol ts that mi grate past Sunnysi de Dam nay be di verted from the Yaki ma River into the Sunnysi de Canal and must pass through the Sunnysi de Screening Facility before ret urning to the ri ver. Sal nonid popul ati ons passing through the Sunnysi de Screeni ng Faci lity i ncl ude both speci es tested; steel head and spring chi nook sal mon.

St eel head

Steel head used in our studi es were snol ts that had an average wei ght of 11 to $13 \mathrm{fi} \mathrm{sh} / \mathrm{kg}$ and an average fork I ength (FL) of 16 $\mathrm{cm}$ to $23 \mathrm{~cm}$ Fi sh were obtai ned from the Whshi ngt on State Department of Gane ( VDG) and were from stocks desi gnated for pl anting i $n$ the upper Yaki na Ri ver Basi $n$. The steel head were hatched at the WDG Naches Trout Hatchery and reared at the Nel son Spring Rearing station. The fish were cold branded and thei $r$ adi pose fi $\mathrm{n}$ was $\mathrm{cl}$ i pped. The brand was a $1.25-\mathrm{cm} \times 0.2-\mathrm{cm}$ bar applied horizontally above the I ateral I i ne in one of four locations: ri ht or left anterior (RA LA), or right or left posteri or (RP, LP4, Branded fi sh were hel d at the Naches Trout Hatchery until thei $r$ rel ease at the Sunnysi de Screens.

Chi nook Sal mon

Chi nook sal mon used in our st udi es were smol ts that had an average wei ght of 31 to $35 \mathrm{fi} \mathrm{sh} / \mathrm{kg}$ and an average FL of $12 \mathrm{~cm}$ to $16 \mathrm{~cm}$ They were obtai ned from the U.S. Fi sh and Vild if e Servi ce, Leavenuorth Nati onal Hatchery. The fi sh were col d branded, wi re coded tagged (Code \#5-17-5), and thei $r$ adi pose fi $n$ was cl i pped. The brand was a $1.25 \mathrm{~cm} \times 0.2 \mathrm{~cm}$ bar appl i ed hori zontally above the I ateral I i ne in one of four locations: RA, LA, RP, LP. The branded fi sh were hel $d$ at the Leavenworth National Hatchery until thei $r$ rel ease at the Sunnysi de Screens. 


\section{SAMPLING EQU PMENT}

The st udy objecti ves requi red that rel eased fi sh be capt ured wi thi $n$ the screeni ng facility and at the termus of the pri nary fi sh return pi pe. Thi s uas accompl i shed with the devel opment of an i ncli ned pl ane and fyke net that uere customfit to the Sunnysi de Screens. Sampl i ng equi pment al so i ncl uded faci I i ti es for hol ding fish for post-testing observations.

I ncl i ned PI ane

Fi sh were capt ured by $\mathrm{pl}$ aci ng an i ncl i ned pl ane i $\mathrm{n}$ the fl ow control structure (Fi gure 5 ). The $\mathrm{pl}$ ane was made of stai $\mathrm{nl}$ ess steel and was desi gned to fit snugl $y$ into the terminus of the fl ow control structure. The pl ane was $4.6 \mathrm{~m} \mathrm{I}$ ong and $0.6 \mathrm{~m}$ wi de; the surface area of the plane was about $2.6 \mathrm{~m}^{2}$. The frane of the pl ane was made from $1.3 \mathrm{~cm} \times 7.6 \mathrm{~cm}$ steel bar that was braced with steel bars uel ded at al nost equi di stant i nterval s al ong the l ength of the frane. Steel bars $2.5 \mathrm{~cm}$ w de and $4.6 \mathrm{~m}$ I ong were added to the top of the frame to filter fish fromthe water. The bars were bent i $n$ the middle al ong thei $r$ I ength at a 45 degree angle and wel ded to the frame, angle apex facing away from the frame. The spaci ng bet ween the bars was $0.63 \mathrm{~cm}$ A l i ve-box constructed of stai $\mathrm{nl}$ ess steel ( $1.2 \mathrm{~m} \times 0.6 \mathrm{~m} 1001$ capacity) was fastened to the downstream end of the $\mathrm{pl}$ ane.

Whter fl ow was di rected over the pl ane by pl aci ng dam boards in the upstream stopl og sl ots of the fil ow control structure terminus. The dam board was $66 \mathrm{~cm}$ wi de and $2.5 \mathrm{~m} \mathrm{hi} \mathrm{gh.} \mathrm{The}$ upstreamend of the plane was bolted to the top portion of the dam board. The l evel of the pl ane was adj ustable. The pl ane was I owered into the fl ow control structure with a winch until the surf ace of the pl ane was compl etel y subnerged and the fl ow of uater entering the I i ve-box was sufficient to "Iift" fish fromthe pl ane into the box.

\section{Fyke Net}

Fi sh were captured at the terminus of the primary fish return pi pe with a $6.0 \mathrm{ml}$ ong fyke net (Fi gure 6) made of $1.0-\mathrm{cm}$ mesh knotless nyl on netting. The net nouth was $1.2 \mathrm{~m} \times 2.3 \mathrm{mtapering}$ to a $25 \mathrm{~cm} \times 63 \mathrm{~cm}$ cod end. A zi pper was i nstal led in the cod end of the net to accommodate the removal of $f i s h$.

Hol ding Facilities

Four $f i$ bergl ass $f i$ sh troughs were i nstal l ed on si te at the Sunnysi de Screens. The troughs were $3 \mathrm{ml}$ ong, $0.6 \mathrm{~m}$ wi de, and 0.3 m deep (1000 1 capacity). Whter was suppl i ed to the troughs at 


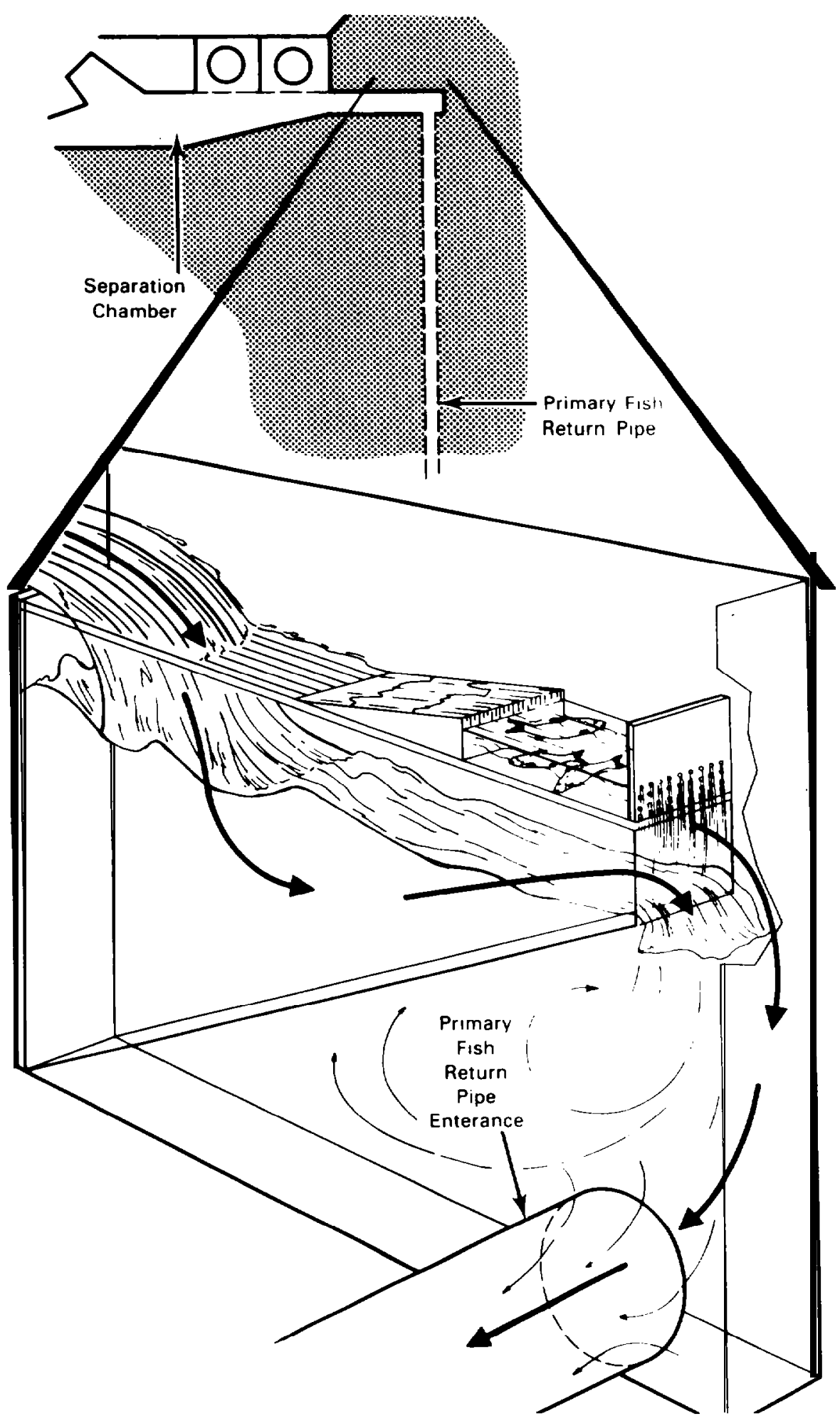

FI GRE 5. I ncl i ned PI ane System Used at the Sunnysi de Canal Fi sh Screening Facility, Spring 1985 


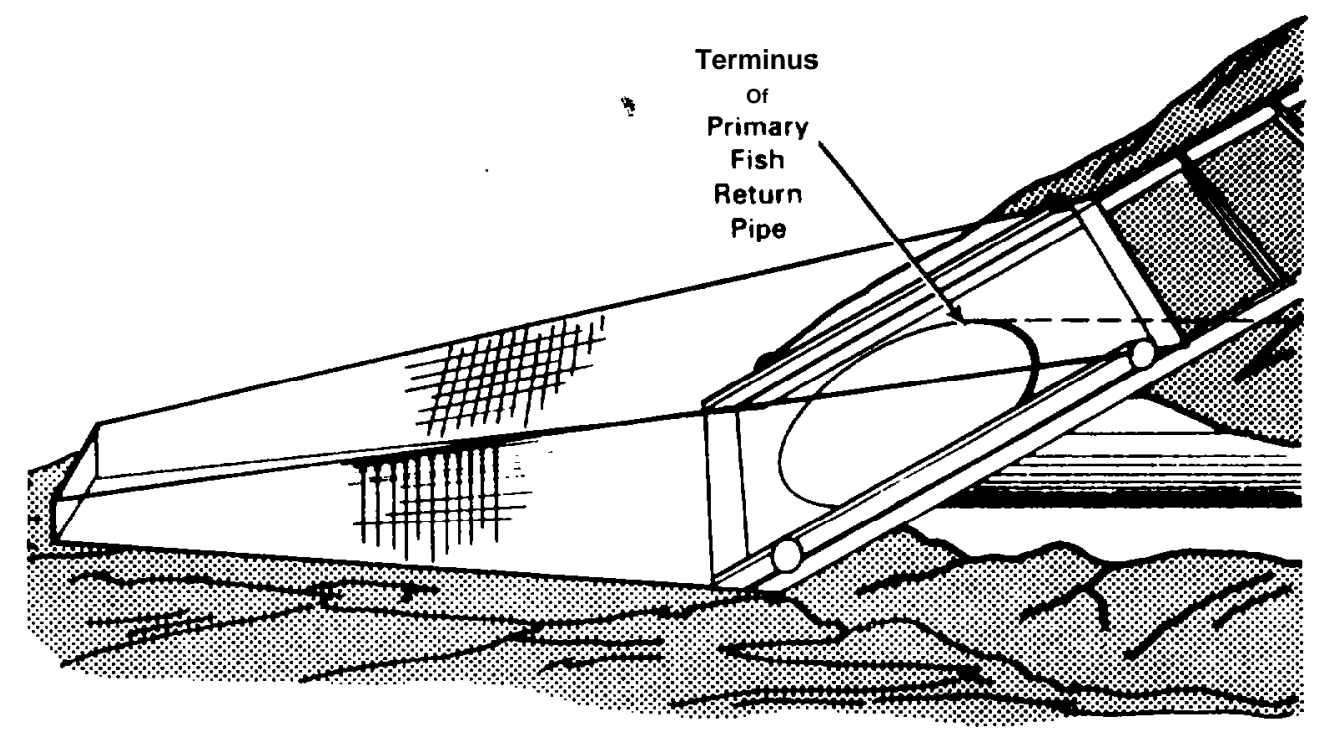

FI GRE 6. Fyke Net Used at the Sunnysi de Canal Fi sh Screening Facility, Spring 1985

$201 / \mathrm{min}$ from the fi shwater return pumps. Fi sh were hel $\mathbf{d}$ in the troughs after renoval from the live-box or net until thei $r$ scale conditi on was eval uated. Sone $f i$ sh were hel $d$ in the troughs for post-test observati ons.

\section{DESCALI NG EVALUATI ON}

The system devel oped by the U.S. Army Corps of Engi neers (Basham et al. 1982) was used to eval uate the scal e condi ti on of fi sh at the Sunnysi de Screens. The eval uati on criteria i ncl uded modi fi cati ons establ i shed i n earl y 1985 (Appendi x A). A basel i ne descal i ng condi ti on was determi ned by randonl y sampl ing the test popul ati ons pri or to rel ease.

The extent of scal e I oss was determi ned by examini ng the descaling that occurs i $n$ each of ten equal areas, $f i$ ve on each si de of the fish (Figure 7 ). If $40 \%$ or nore scal e I oss is observed in any two areas on one side of a fish, the fish was cl assified as descal ed. A sample score sheet is al so shown in Appendi x A 

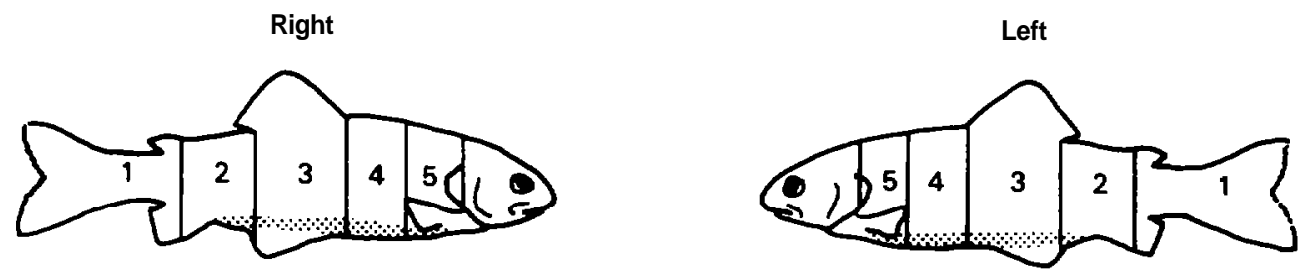

FI GRE 7. Di vi si on of Body Areas to Eval uate Scal e Loss on Sal noni ds at Sunnysi de Canal Fi sh Screening Facility, Spring 1985

\section{TEST PROCEDURE}

Fi sh were rel eased ei ther in the canal or wi thi $\mathbf{n}$ the screening facility depending on the test objective. Fi sh were rel eased into the canal to quantify descaling and nortalities caused by the enti re screening facility (canal headgates to the river). Fish were rel eased within the screening facility to identify screening components downstream of the rotating screens that might descal e or ki ll fish. Additionally, fish passage ti me through the screening facility and identification of possible predat or populations within or near the Sunnysi de Screens were noni tored.

Fi sh Transport and Rel ease

Test fish were transported by truck in an i nsul ated tank ( 4001 capaci ty) suppl $i$ ed with oxygen. Transit ti me from Naches and Leavenuorth to the Sunnysi de Screens was $0.5 \mathrm{~h}$ and $2.5 \mathrm{~h}$, respecti vel y. Loading densiti es during transport di not exceed $120 \mathrm{~g}$ of $\mathrm{fish} / \mathrm{l}$. No losses attributable to transport were observed for steel head and I ess than $1 \%$ I oss occurred with the chi nook sal non.

Test fi sh were rel eased di rectly from the transport tank into the canal or screening facility ei ther through a $10 \mathrm{~cm}$ di aneter pl astic tube attached to the transport tank or by di $p$ net.

\section{Fi sh Rel ease Locati ons}

Fi sh were rel eased at tuo I ocations in the Sunnysi de Canal : downstream of the canal headgates and dounstream of the trash racks ( Fi gure 2). Fi sh were rel eased at three l ocations wi thi $\mathbf{n}$ the fl ow control structure: in the intermedi ate bypass entrance, 
the terminal bypass entrance, and at the terminus of the fl ow control structure (Fi gure 3).

Rel ease Control s

Bef ore rel ease, 10 to $50 \mathrm{fi}$ sh were randonl y sampl ed from the group. These fi sh were anest het i zed and eval uat ed for scal e I oss or i nj ury to segregate transport and hatchery descal ing from descal ing caused by the screening facility. Fi sh were al so rel eased on the inclined plane or placed in the net to determine scal e I oss resulting from the sampling equi pnent.

Fi sh Capt ure and Eval uati on

Capt ured fi sh were di $p$ netted from the I $i$ ve box on the i ncl i ned pl ane with a net and pl aced in a hol di ng trough. Fi sh were then anesthetized wi th Mb-222, scal e I oss was eval uated, and fi sh were ret urned to the hol di ng troughs. Some fi sh were hel d for post-test observati on to determine the potent $i$ al for del ayed mortality. After fish had recovered fromt he anesthetic and the post-test observati ons were compl ete, fish were ret urned to the Yaki na Ri ver.

\section{STATI STI CAL ANALYSI S}

Esti nates of the percent of fish descal ed or killed were based on the number of test fi sh that were caught. Descal ed fish were consi dered as dead for eval uati on of the results. Conf $i$ dence i nterval s for these esti nates were cal cul at ed from Mai nl and's Tabl es (Mi nl and et al. 1956). Data for repl i cate tests were conbi ned to obtai $n$ a nean esti mate. The esti mate assumes each fi sh behaved independently (i.e. fish within a test did not behave nore si milarly than fish bet ween tests and there were no interactions anong $f i s h$ wi thi $n$ a test). A though some i nteraction is expected anong fish, it is an assumpti on necessary for the anaI yti cal nethods used. A I tests were conducted in the same manner to reduce non-i ndependent behavi or of $\mathrm{fi}$ sh. 
RESULTS AND DISCUSSION

The resul ts of our tests indi cate that $f i$ sh pass saf el $y$ through the Sunnysi de Screen Facility. The obj ecti ves and resul ts of each of the tests are di scussed bel ow A detail ed summary of the catch data and the esti mates for percent ot test fi sh that were descal ed or ki Il ed are presented in Appendi X B.

\section{RELEASE AND CAPTURE TESTS}

Thi rty groups of $f i$ sh were rel eased at fi ve different l ocati ons. A t ot al of 4492 chi nook sal mon were rel eased; 3625 were subsequent l y capt ured and 1672 steel head were rel eased; 507 were capt ured. Less than $2 \%$ of the chi nook sal mon were descal ed or killed. These l osses are well wi thi $n$ the $95 \%$ conf $i$ dence interval for the condition of the control s (Appendi $j x$ B). None of the st eel head were descal ed or ki l led.

Pri mary Fi sh Return Pi pe

Test fish survived passage through the primary fish return pi pe to the river. The pi pe is the I ast component of the fil ow control structure; it is $21 \mathrm{ml}$ ong and $1.2 \mathrm{~m}$ i $\mathrm{n}$ di ameter. Fl ow rate through the pi pe is about $0.6 \mathrm{~m}^{3} / \mathrm{sec}$. Duri ng nornal operati on al I fish di verted fromthe canal toward the river pass through' the pri mary fish return pi pe.

The effect of passage through the pri mary fish return pi pe was eval uated independently from the rest of the fl ow control structure because the inclined plane operated most efficiently upstream of the pi pe entrance. None of the steel head and $0.8 \%$ of the chi nook sal non were descal ed or killed after passing through the pi pe (Tables 1 and 2).

\section{Intermediate Bypass Ent rance}

Testt fish survi ved passage through the internedi ate bypass entrance. During normal operation, fl ow through this bypass entrance is about $1.4 \mathrm{~m}^{3} / \mathrm{sec}$. Assuming a uni form di stribution, upstream of the screens, hal $f$ the fish that are di verted into the canal wi 111 enter the internedi ate bypass.

Fi sh that enter the fl ow control structure at the i ntermedi ate bypass entrance nay pass ei ght of the rotating screens ( Fi gure 2). These fish will have to pass the intermedi ate bypass entrance gui dance wal I, the i nternedi ate bypass pi pe, the secondary separation chanber, and the pri nary fish return pi pe bef ore ret urning 
TABLE 1. Descal i ng and Mbrtal it y Data from Rel ease and Capt ure Test s wi th Chi nook Sal mon, Oncorhynchus t shawyt scha, Snolts at the Sunnysi de Canal Fish Screening Facility, Spring 1985

\begin{tabular}{|c|c|c|c|c|c|}
\hline \multirow[b]{2}{*}{$\begin{array}{l}\text { RELEASE } \\
\text { SI TE }\end{array}$} & \multicolumn{3}{|c|}{ NUMBER OF FI SH } & \multirow{2}{*}{$\begin{array}{c}\text { FI SH } \\
\text { DESCALED } \\
\text { KI LLED } \\
\end{array}$} & \multirow{2}{*}{$\begin{array}{c}95 \% \\
\text { OR CONFI DENCE } \\
(\%) \text { INTTEPVAL } \\
\end{array}$} \\
\hline & RELEASEL & CAPTURED & $\begin{array}{l}\text { LESCALED D } \\
\cap R \quad \mathbf{K} \text { LLED }\end{array}$ & & \\
\hline FISH RETURN & & & & & \\
\hline PIPE & 500 & 371 & 3 & 0.8 & $0.2-2.3$ \\
\hline $\begin{array}{l}\text { I NTERMEDI ATE } \\
\text { BYPASS }\end{array}$ & 500 & 468 & 4 & 0.9 & $0.2-2.2$ \\
\hline $\begin{array}{l}\text { TERM NAL } \\
\text { BYPASS }\end{array}$ & 492 & 476 & 7 & 1.5 & $0.6-3.0$ \\
\hline TRASH RACK & 1000 & 856 & 20 & 2. 3 & $1.4-3.6$ \\
\hline $\begin{array}{l}\text { CANAL } \\
\text { HEA.DGATES }\end{array}$ & 2000 & 1454 & 28 & 1.9 & 1. 3- 2.8 \\
\hline
\end{tabular}

TABLE 2. Descal ing ar.d Mortality Data from Rel ease and Capt ure Tests wi th Steel head, Sal mo gai rdneri Snol ts at the Sunnysi de Canal Fi sh Screening Facility, Spring 1985

\begin{tabular}{|c|c|c|c|c|c|}
\hline \multirow[b]{2}{*}{$\begin{array}{l}\text { RELEASE } \\
\text { SITE } \\
\end{array}$} & \multicolumn{3}{|c|}{ NUMER OF FI SH } & \multirow{2}{*}{$\begin{array}{c}\text { FISH } \\
\text { DESCALED } \\
\text { K LLED }\end{array}$} & \multirow{2}{*}{$\begin{array}{c}95 \% \\
\text { OR CONIF IDENCE } \\
\text { (\%) I NIERVAL }\end{array}$} \\
\hline & RELEASED & CAPTURED & $\begin{array}{l}\text { DESCALED D } \\
\text { CR K LLED }\end{array}$ & & \\
\hline $\begin{array}{l}\text { FI SH RETURN } \\
\text { PI PE }\end{array}$ & 172 & 30 & C & C & C- 11.6 \\
\hline $\begin{array}{l}\text { I NTERMED ATE } \\
\text { BYPASS }\end{array}$ & 275 & 139 & 0 & 0 & 0.2 .6 \\
\hline $\begin{array}{l}\text { TERMNAL } \\
\text { B Y P A S S }\end{array}$ & 200 & 112 & 0 & 0 & 0.3 .2 \\
\hline TRASH RACK & 500 & 126 & 0 & 0 & $0-2.9$ \\
\hline $\begin{array}{l}\text { CANAL } \\
\text { HEADGATES }\end{array}$ & 500 & 100 & 0 & 0 & 0.3 .6 \\
\hline
\end{tabular}


to the river. None of the steel head and $0.9 \%$ of the chi nook sal non were killed or descal ed during tests through the internedi ate bypass entrance (Tables 1 and 2).

Termi nal Bypass Entrance

Test fish survi ved through the terminal bypass entrance. During normal operation, fl ow through this bypass entrance is about $1.4 \mathrm{~m}^{3} / \mathrm{sec}$. Assumi ng a uni form di stri but i on, upst ream of the screens, half of the fish that are di verted into the canal will enter the terminal bypass entrance.

Fi sh that enter the fl ow control structure at the terminal bypass entrance may pass ni ne of the rotating screens (Figure 2). These fish will have to pass by or through the terminal bypass entrance, the secondary separation chamber, and the primary fish return pi pe bef ore bei ng returned to the river. None of the steel head and $1.5 \%$ of the chi nook sal mon were killed or descal ed during tests through the terminal bypass entrance (Tables 1 and 2).

\section{Trash Rack}

Test fish survi ved passage to the river after rel ease downstream of the trash rack. During normal operation, fish pass through the trash rack and into the flow control structure at the internedi ate or terminal bypass entrance. Al fish that enter the canal and return to the river through the pri mary fish return pi pe pass through the trash rack. Fi sh downstream of the trash rack have passed fromthe canal headgates to withi $3 \mathrm{~m}$ to $60 \mathrm{~m}$ of the rotating screens (Figure 2 ). These fish may pass ni ne rotating screens. Before returning to the river the fish must pass through the fl ow control structure and the primary fish return pi pe. None of the steel head and $2.3 \%$ of the chi nook sal mon were killed or descal ed during passage through the trash rack (Tables 1 and 2 ).

\section{Canal Headgates}

Test fish survi ved passage to the river after rel ease downstream of the canal headgates. Assuming uni form fi sh di stributi on above Sunnysi de Dam about $75 \%$ of the fi sh in the Yaki ma Ri ver may be di verted through the Sunnysi de Canal Fi sh Screening Facility. Fl ow through the canal ranges from about $17 \mathrm{~m}^{3} / \mathrm{sec}$ to $37 \mathrm{~m}^{3} / \mathrm{sec}$ duri ng the i rrigati on season (March through October). Yaki ma Ri ver fl ow at Sunnysi de Dam can vary from $3 \mathrm{~m}^{3} / \mathrm{sec}$ to $425 \mathrm{~m}^{3} / \mathrm{sec}$ during the same period. Whter use agreenents have established a mi ni mum fl ow of $6 \mathrm{~m}^{3} / \mathrm{sec}$ across Sunnysi de Dam when possi bl e. Therefore, up to $75 \%(17 /(6+17) \times 100=75)$ of the Yaki ma Ri ver may be di verted i nto the Sunnysi de Canal. 
Whter di verted i nto the Sunnysi de Canal at Sunnysi de Dam enters through the canal headgates. Al fish that enter the canal enter through the canal headgates and pass through about $360 \mathrm{~m}$ of canal bef ore reaching the screen structure. In our tests, none of the steel head and $1.9 \%$ of the chi nook sal non were ki Iled or descal ed during passage through the canal headgates (Tabl es 1 and 2).

\section{DESCALI NG OF HATCHERY-RELEASED AND NATI VE FISH}

Duri ng our tests, we col I ected many hat chery-rel eased and nati ve Yaki ma River fish. Tuo hundred and fifty sal moni ds were anest het i zed and checked for scal e l oss (Table 3 ). Ten fi sh were descal ed. A though the condition of the fish entering the canal headgates is unknown, the number of descal ed fi sh indi cates that the Sunnysi de Screens are not descaling fish as they are diverted from the canal back to the Yaki ma Ri ver.

TABLE 3. Scal e Loss for Hatchery-Rel eased and Nati ve Fi sh Capt ured during Tests at the Sunnysi de Canal Fi sh Screeni ng Facility, Spri ng 1985

\begin{tabular}{|c|c|c|c|c|}
\hline $\begin{array}{l}\text { DATE } \\
\text { CQLECTED }\end{array}$ & SPECI ES & ORIGIN & $\begin{array}{c}\text { NUMBER } \\
\text { COLLCTED }\end{array}$ & $\begin{array}{c}\text { NUMBER } \\
\text { DESCALED }\end{array}$ \\
\hline Apri I 30 & chi nook sal non & hat chery & 14 & 0 \\
\hline Apri I 30 & chi nook sal mon & nat i ve & 28 & 1 \\
\hline April 30 & st eel head & hat chery & 1 & 0 \\
\hline April 30 & st eel head & nati ve & 4 & 0 \\
\hline May 9 & chi nook sal non & hat chery & 25 & 0 \\
\hline My 9 & chi nook sal non & nati ve & 4 & 0 \\
\hline May 13 & chi nook sal mon & hat chery & 5 & 0 \\
\hline May 13 & chi nook sal mon & nati ve & 2 & 0 \\
\hline May 13 & st eel head & nati ve & 1 & 0 \\
\hline My 16 & chi nook sal non & hat chery & 17 & 1 \\
\hline My 16 & chi nook sal non & nati ve & 12 & 1 \\
\hline May 16 & st eel head & hat chery & 4 & 0 \\
\hline My 16 & st eel head & nati ve & 3 & 0 \\
\hline My 17 & chi nook sal non & hat chery & 35 & 1 \\
\hline May 17 & chi nook sal non & nati ve & 30 & 3 \\
\hline My 17 & st eel head & hat chery & 1 & 0 \\
\hline May 17 & st eel head & nati ve & 2 & 0 \\
\hline Myy 28 & chi nook sal mon & hat chery & 22 & 2 \\
\hline Myy 28 & chi nook sal non & nati ve & 20 & 0 \\
\hline Myy 28 & st eel head & hat chery & 8 & 0 \\
\hline May 28 & st eel head & nati ve & 12 & 1 \\
\hline
\end{tabular}




\section{FISH PASSAGE TIME THROUGH THE SCREEN NG FACILITY}

The rate at which fish move through the screen facility depends on the mi grat ory behavi or of a speci es, ti me of day, and rel ease I ocation. We recorded the the amount of ti me requi red or taken for fish that we rel eased into and upstream of the screening facility. If fish are attracted to or are unable to swi m out of the screening facility they are lost to the enhancenent efforts in the Yaki ma Ri ver Basi n. Canal fl ow does not appear to "fI ush" fi sh through the facility, however test fish did not appear to resi dual ize in the screening facility.

Chi nook sal mon rel eased i nto the canal moved to the i ncl i ned pl ane qui cker than steel head. Rel eases of 500 steel head were made at the canal headgates and at the trash rack. Si xty-seven hours af $t$ er rel ease, $20 \%$ of the steel head rel eased at the canal headgates and $25 \%$ of the steel head rel eased at the trash rack were capt ured ( Fi gures 8 and 9). Tho rel eases of 1000 chi nook sal non each were made at the canal headgates and one at the trash rack. Twenty-t wo hours after the fi rst canal headgates rel ease, $76 \%$ of the fish were captured; $16 \mathrm{hr}$ after the second rel ease, $73 \%$ of the fi sh were captured. Si xteen hours after chi nook sal non were rel eased at the trash rack, 82\% were capt ured ( Fi gures 10-11).

A though rel eases were not made at the sane ti me the results suggest that the steel head renai ned in the canal I onger than chi nook sal mon. The difference in behavi or may reflect species differences, size differences, or stage of snol t transf ormation; st eel head, appeared to have l ost sone of thei $r$ external snol $t$ characteristics at the ti ne of thei $r$ rel ease into the canal.

Mbvement of steel head and chi nook sal mon appeared to be i nf I uenced by ti me of day or photoperi od. Steel head were nore I i kel y to enter the i ncl i ned pl ane between $2000 \mathrm{hr}$ and $0400 \mathrm{hr}$ (Fi gures 8 and 9). For the two steel head rel eases into the canal, $77 \%$ and $84 \%$ of the fi sh were capt ured bet ween $2000 \mathrm{hr}$ and $0800 \mathrm{hr}$. Chi nook sal mon were nore I i kel y to nove into the i ncl i ned pl ane bet ween $0400 \mathrm{hr}$ and $0800 \mathrm{hr}$ ( Fi gures 10-11). For the three chi nook sal mon rel eases, $23 \% 32 \%$ and $40 \%$ of the fi sh were capt ured bet ween $0400 \mathrm{hr}$ and $0800 \mathrm{hr}$. A though the correl ati on bet ween ti me of day and capt ure is not as evi dent for chi nook sal mon as for steel head, the trend touard early mroni $n$ novenent appears in the percent caught over ti me (Fi gures 10-114. The trend is al so indi cated by comparing the catch per unit effort presented as a percent of rel eased fish that were remaining to be caught (Fi gures 12-14). 


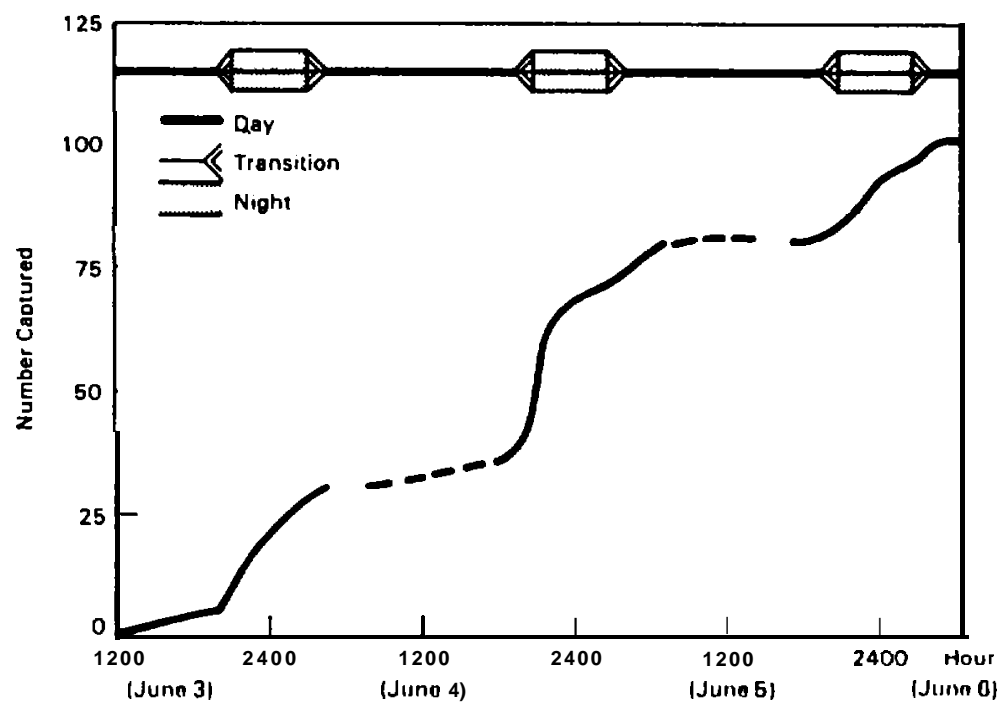

FI GRE 8. Ti ming of Capt ure for Steel head, Sal no gai rdneri, Rel eased Downstream of the Canal Headgates at Sunnysi de Canal Fi sh Screening Facility, Spring 1985

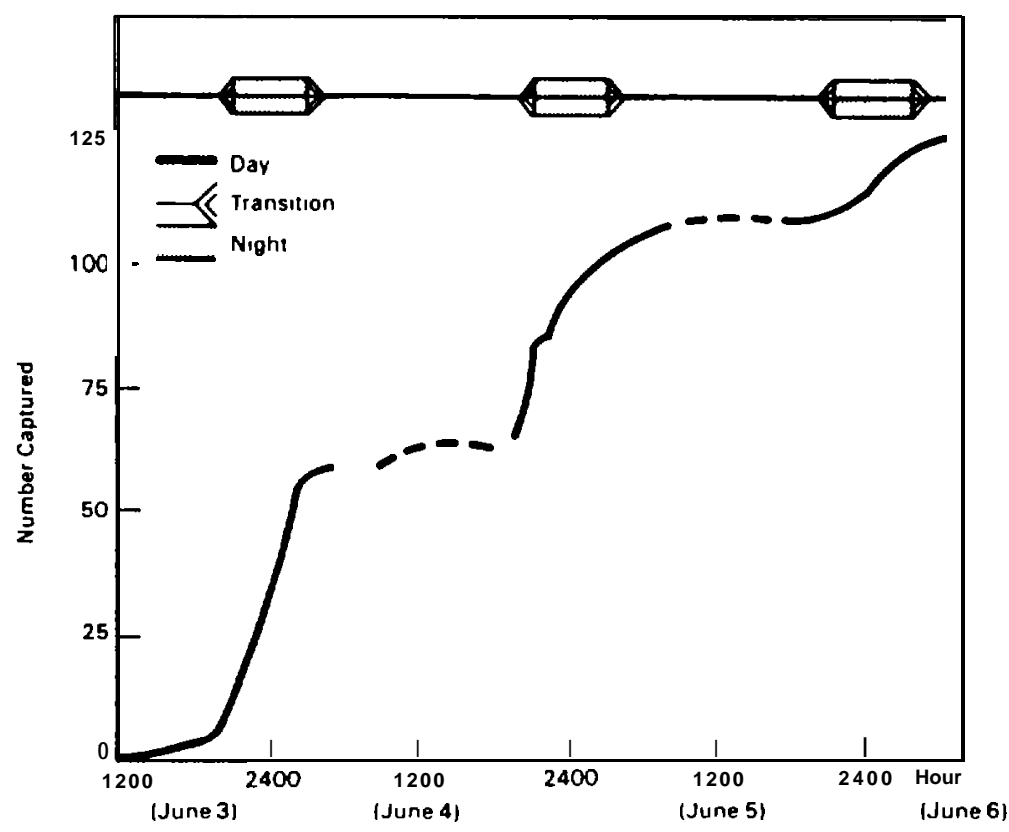

FIGURE 9. Ti ming of Capt ure for St eel head, Sal no gäiráneri, Rel eased Downst ream of the Trash Rack at the Sunnysi de Canal Fi sh Screeni ng Faci lity, Spri ng 1985 


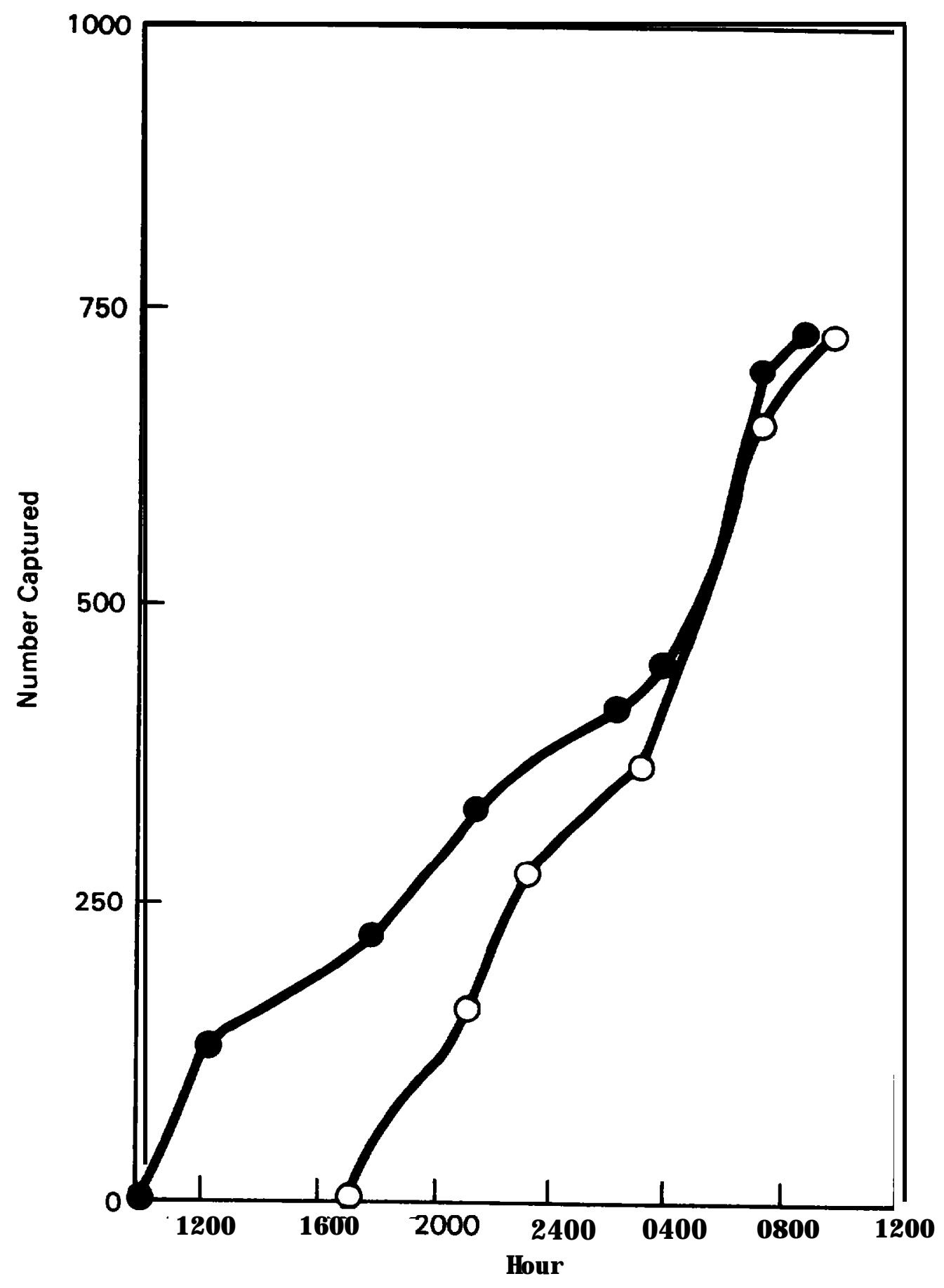

FI GRE 10. Ti ming of "capture for Chi nook Salmon, Oncorhynchus t shauyt scha, Rel eased Dounst ream of the Canal Feadgates at the Sunnysi de Canal Fi sh Screeni ng Facility, Spring 1985 (@ J une 11 test, of une 19 test) 


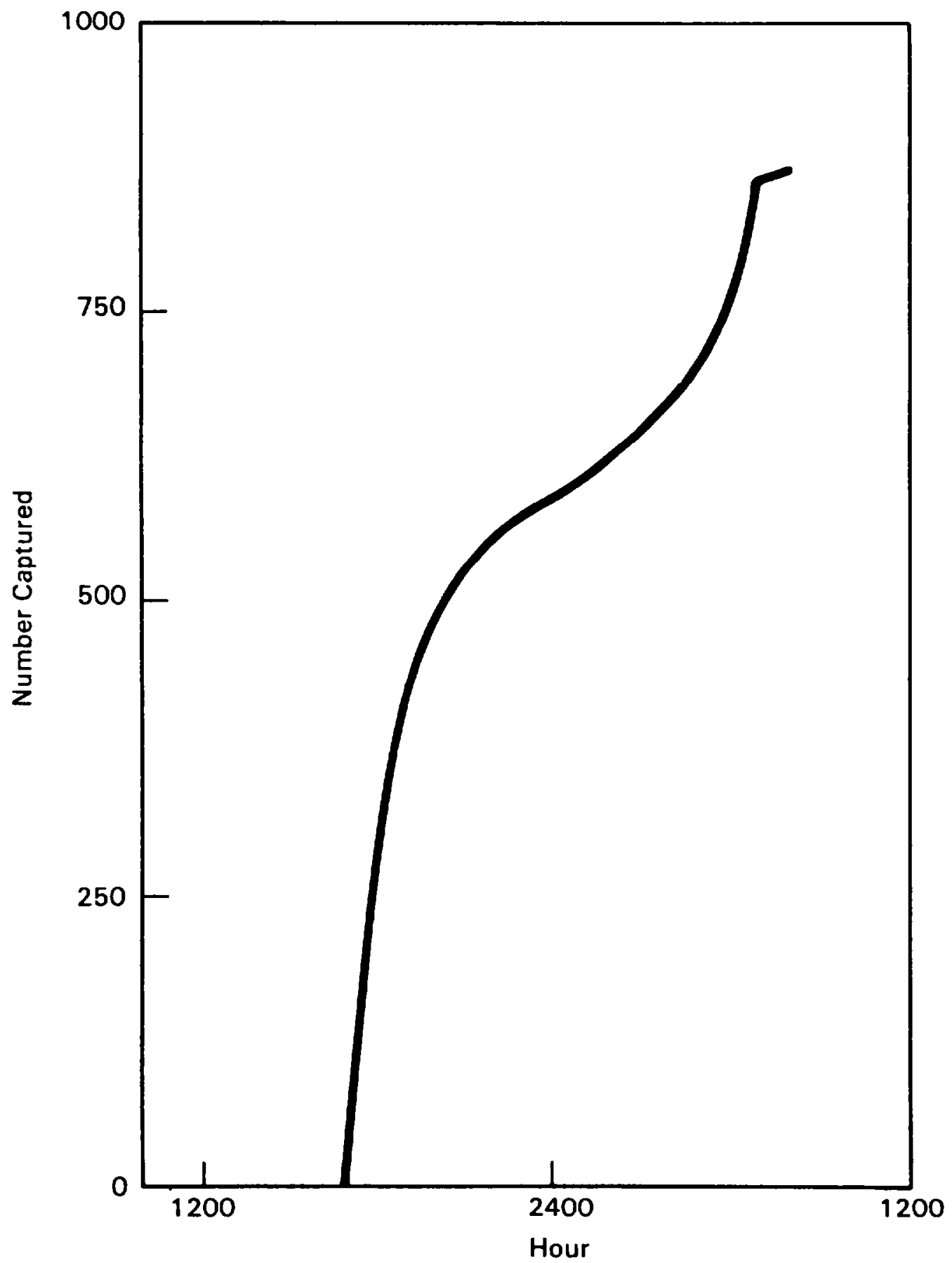

FIGURE 11. Timing of Capture for Chinook Salmon, Oncorhynchus tshawytscha, Released Downstream of the Trash Rack at Sunnyside Canal Fish Screening Facility, Spring 1985

22 

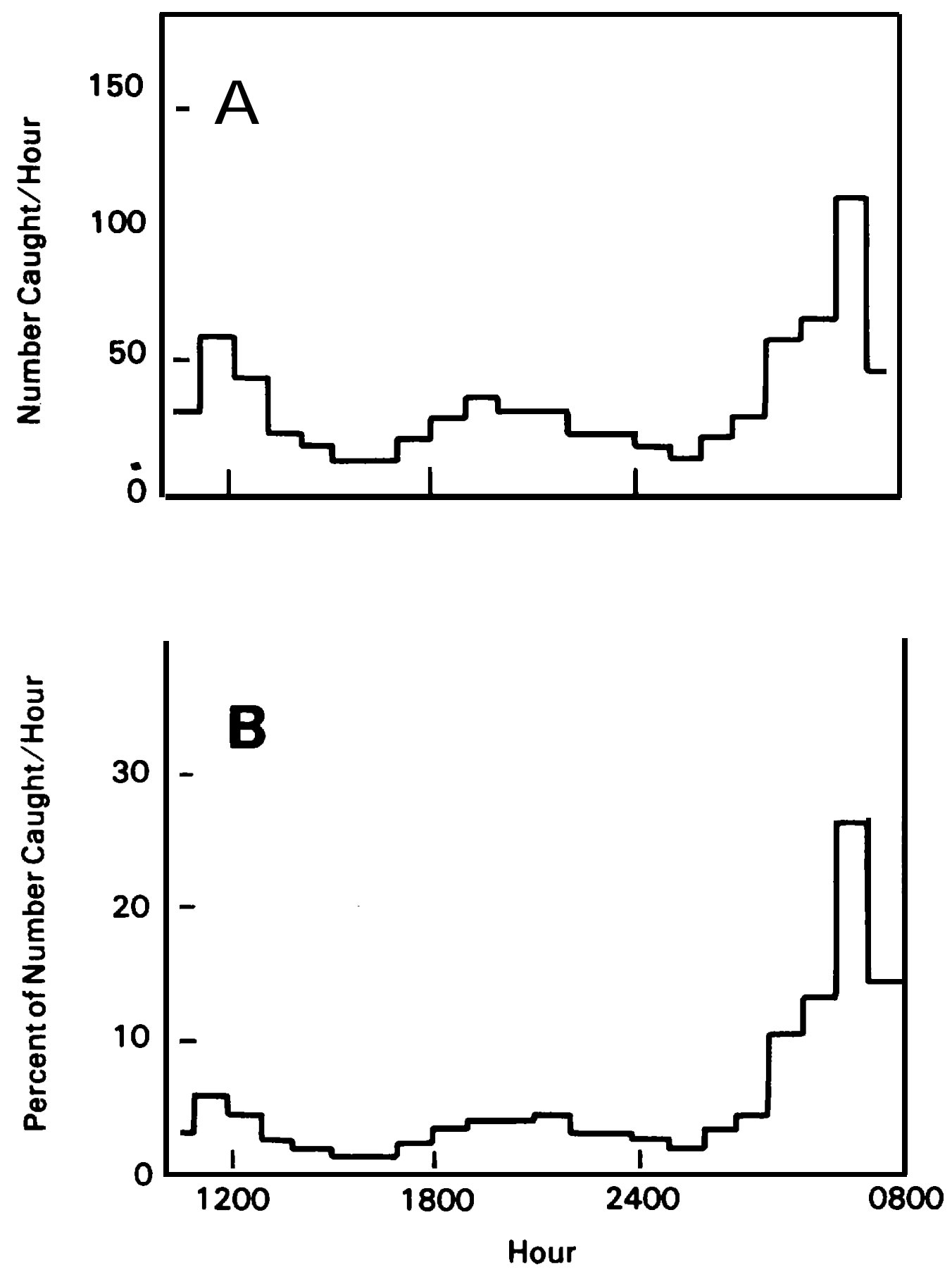

FI GRE 12. Catch Per Unit Effort for Chi nook Sal non, Oncorhynchus tshawytscha, as A) Number of Fi sh Capt ured in Each Sample and B) as a Percent of the Rel eased Fi sh that Were Renai ni ng to be Capt ured (Canal Headgates Test June 11, 1985) 

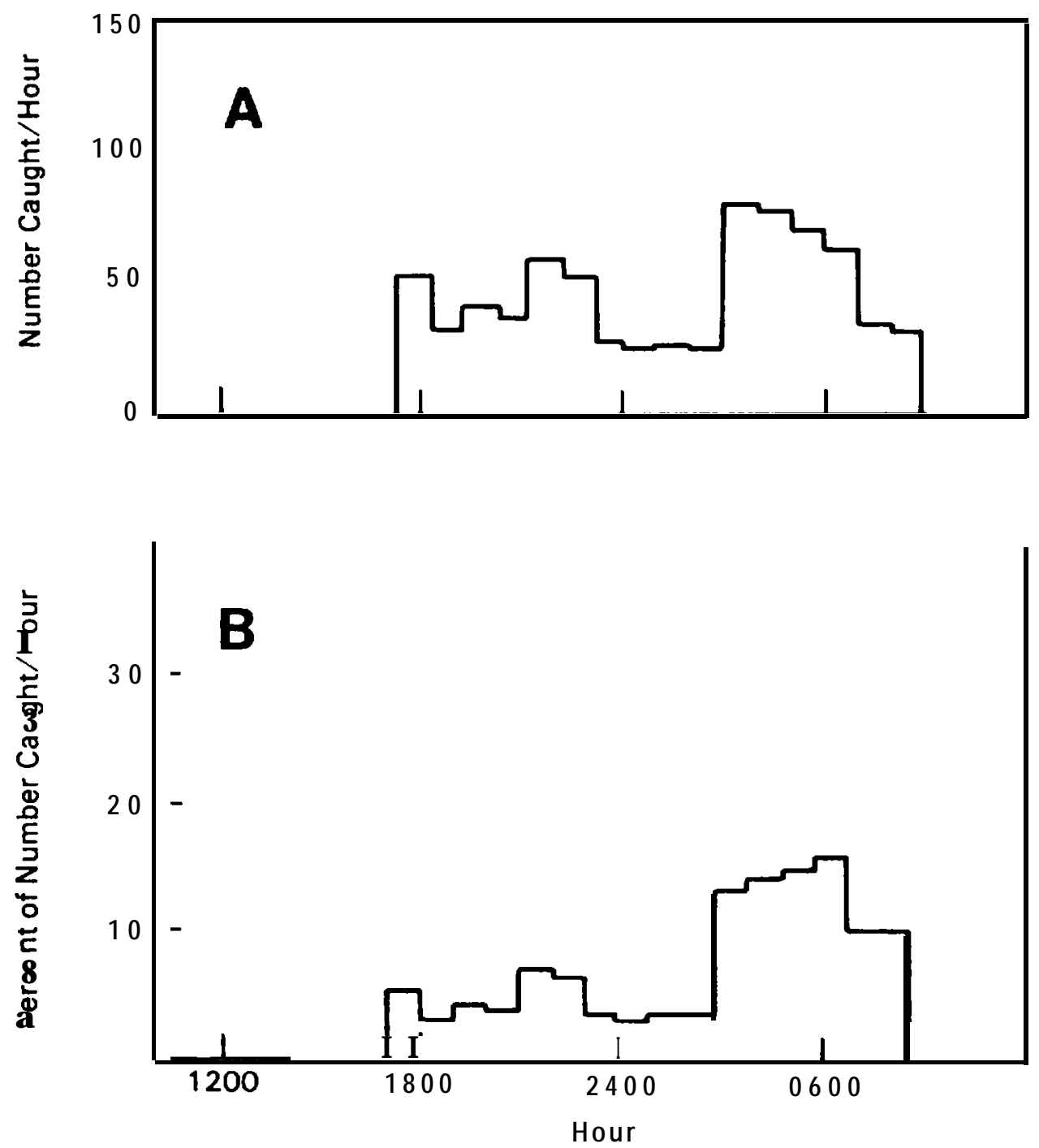

FI GURE 13. Catch Per Unit Effort for Chi nook Sal mon, Oncorhychus tshawytscha, as A) Nunber of Fi sh Capt ured in tach Sample and B) as a Percent of the Rel eased Fi sh that Were Renai ni ng to be Capt ured (Canal Headgates Test J une 19,1985) 

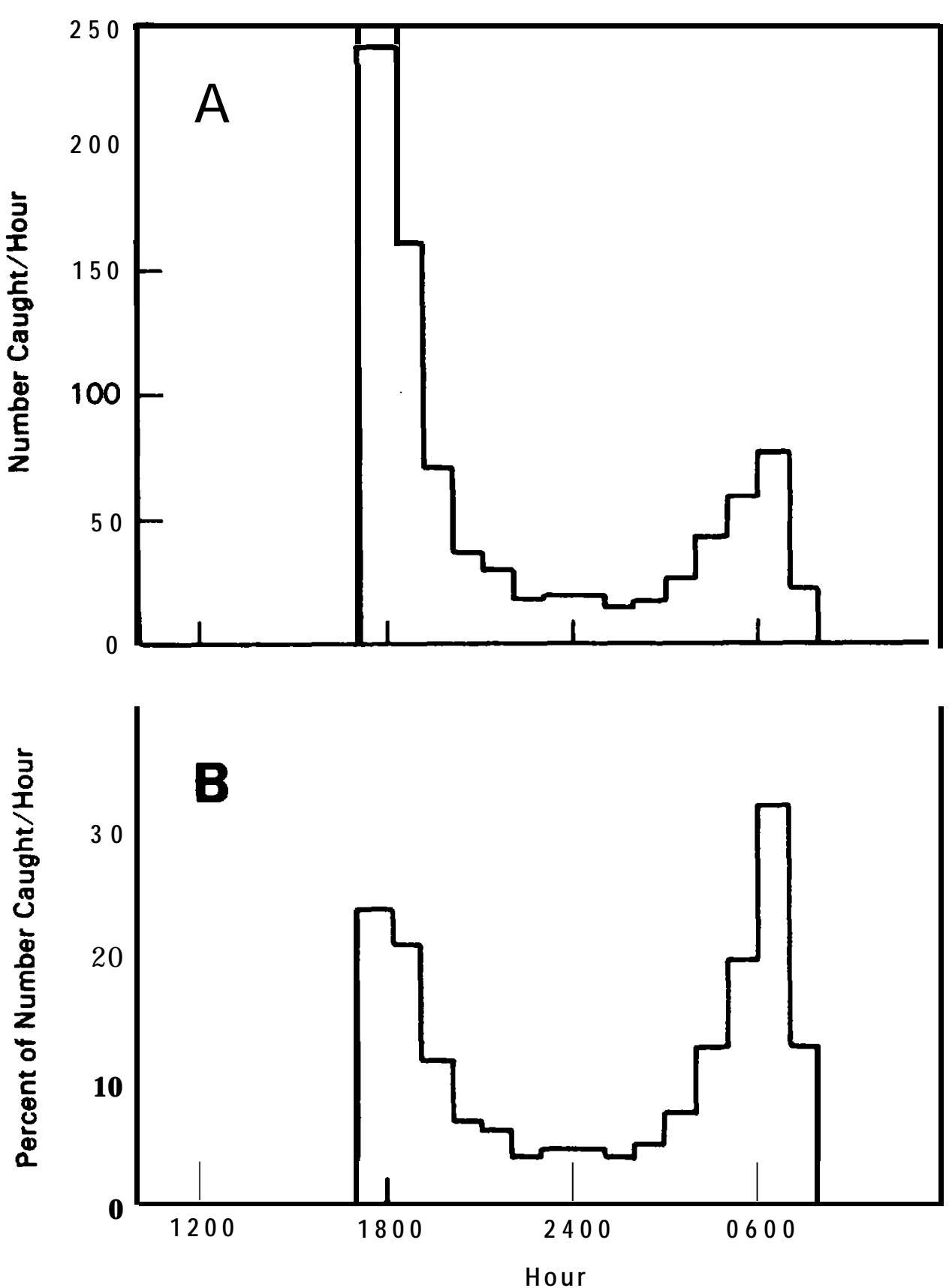

FI GRE 14. Catch Per Unit Effort for Chi nook Sal non, Oncorhychus tshawytscha, as A) Number of Fi sh Capt ured in Each Sample and B) as a Percent of the Rel eased Fi sh that Were Remai ni ng to be Capt ured (Trash Rack Test, Spring 1985) 


\section{PREDATI ON}

Pi sci vor ous predat ors di d not concent rate upst ream of the Sunnysi de Screens. Few predators were captured during our studi es with steel head and chi nook sal mon. Mst nonsal noni ds col l ected uere chi sel mout $h$, Acrochei I us al ut aceus, and suckers, Cat ost omis spp. There were no concentrations of bi rds at the canal headgates or the terminus of the fish return pi pe. There were some ki ngf i shers, Mégaceryle a lcyon, observed near the rai I road trestle downstream of the primary fish return pi pe They were feeding in the pools and riffles on the opposite si de' of the river from the screen facility. 
Rel ease and capt ure tests were conducted at the Sunnysi de Canal Fi sh Screeni ng Faci I ity (Sunnysi de Screens) wi th chi nook sal non and steel head snol ts to eval uate the effecti veness of the screens in safel y di verting fi sh fromthe Sunnysi de Canal to the Yaki na Ri ver. We concl uded that $f i$ sh are saf el $y$ di verted from the Sunnysi de Canal to the Yaki ma Ri ver by the Sunnysi de Screens.

Thi s concl usi on is based on the results of our tests.

- Chi nook sal mon and st eel head snol ts rel eased upstream of or into the Sunnysi de Screens were safel y di verted to the Yaki ma Ri ver.

- Less than $4 \%$ of the hatchery-rel eased and nat i ve fi sh col l ected al i ve and eval uated during our tests were descal ed.

- Snol ts pass through the Sunnysi de Screen Facility of thei $r$ own vol ition. Fi sh that we rel eased into the canal and other fish that entered the canal through the canal headgates were not trapped nor di d they seem to be attached to any portion of the canal.

- Snol t novenent occurred nai nl y at ni ght.

- Concent rati ons of pi sci vorous predators were not observed i n or near the Sunnysi de Screens.

Fi eld tests were conducted by the Pacific Northwest Laboratory for the Bonnevi I l e Power Admi ni stration. Tests were conducted to assess: fish condition after passage through the screen facility, passage ti me for fish migrating through the screen facility, and possible l oss of di verted fish to predators. 


\section{REFERENCES}

Basham L. R. M R. Del arm 3. B. Athern, and S. W Pettit. 1982. Fi sh Transport at i on Oversi ght Team Annual Report, FY 1981: Transport Operati ons on the Snake and Columbia Ri vers. NOAA Techni cal Menorandum NMFS F/ NMR-2. Envi ronnent al and Techni cal Servi ces Di vi si on, Northuest Regi onal Offi ce, Nati onal Oceani $c$ and At mospheri c Admi ni strati on, Nati onal Mari ne Fi sheri es Servi ce, Portl and, Oregon.

Bur eau of Recl anati on. 1984. Fi ndi ng of No Si gni fi cant Impact: Fi sh Passage and Protecti ve Facilities, Yaki ma Ri ver Basi $n$, Washington. Bureau of Recl anati on, Paci fi c Northuest Regi on, Boise, Idaho.

East er brooks, J. A 1984. J uveni I e Fi sh Screen Desi gn Cri teri a: A Revi ew of the Objectives and Sci entific Data Base. State of Whishi ngt on, Depart ment of Fi sheri es, Habi tat Managenent Di vi si on, Yaki ma, Whshi ngt on.

Hol I oned, J.J. 1984. 1983 Yaki ma Ri ver Fal I Fi sh Counts at Prosser Dam Yaki ma I ndi an Nati on, Fi sheri es Resource Managenent Techni cal Report No. 84- 11 . Yaki ma I ndi an Nati on, Toppeni sh, Wishi ngt on.

Mii nl and, D. , L. Herrera, and M I. Sut cl iffe. 1956. Tabl es for Use wi th Bi nomial Sampl es. Mi nl and, Herrera, and Sutcliffe, New York, New York.

Northwest Power PI anni ng Counci I (NPPC). 1984. Fi sh and Vil dl i fe Program (as amended). Northwest Power PI anning Council, Portl and, Oregon. 
APPENDI X A

CRI TERI A USED TO EVALUATE FI SH DESCALI NG AT THE SUNMSI DE CANAL FI SH SCREENING FACI LI TY, SPRI NG 1985 


\section{CRITERIA USED TO EVALUATE FISH DESCALI NG AT THE SUNNYSIDE CANAL FISH SCREEN NG FACILITY, SPRI NG 1985}

Sal noni d snol t condi ti on is eval uated by esti mating the percent age of scal es that have been I ost. An eval uati on system was standardi zed for use at screening and bypass systens at Col unbi a and Snake Ri ver dans. The system uas devel oped by fi sheri es agenci es that conduct the eval uati ons (Basham et al . 1982, Ral ei gh and Chapnan 1983). The eval uati on assumes that $\mathrm{fi}$ sh that have been descal ed will not survi ve to return upstream as adul ts (Park et al . 1982, Basham et al . 1982). The eval uati on system provi des a common standard for fi sheri es workers in the Pacific Nbrthuest.

Thi s appendi $x$ contai ns a li st of descal ing criteria, a standardi zed score sheet for recording the data, and a I i st of suggested modifications that were to be applied on a trial basis during the 1985 sal noni $d$ out mi grati on. Paci fi c Northwest Laboratory researchers who eval uated $\mathrm{fi}$ sh at the Sunnyside Canal Fish Screening Facility recorded data using both sets of criteria; however, data presented in this report were collected using on the pre-1985, non-tri al standards. The suppl enentary data were col lected for possible future use.

Fi sh scal e conditi on is eval uated by vi sually di vi ding the fi sh into ten approxi matel y equal areas, fi ve on each si de (Figure A.I). Al areas of the fish are examined for scal e loss, except for the ventral surface from the pectoral fins to the vent. The degree or extent of descaling was noted for each fish, as foll ows:

- If scal e I oss was $\leq 3 \%$ in any or al I areas, fi sh condi ti on was noted as "OK".

- If scal e I oss was scattered (diffuse) and $>3 \%$ but $<40 \%$ per area, the fi sh was noted as an Ri ght 6 (R6) and/ or a Left 6 (L6) depending on which si de the scal e loss occurred.

- If scal e I oss was in I ocal i zed areas (patchy) and $>3 \%$ but $<40 \%$ per area, an R6P or an L6P was noted dependi ng on whi ch si de the scal e I oss occurred.

- If scal e l oss was $\mathbf{2 4 0 \%}$ in one or more areas, each area with a $240 \%$ scal e loss was noted by recording the side ( $R$ or $L)$ and the area (I-5) that vere descal ed.

- If the fi sh had an eye or head inj ury, an R7 and/ or L7 was noted. 


\section{Juvenile Descaling}

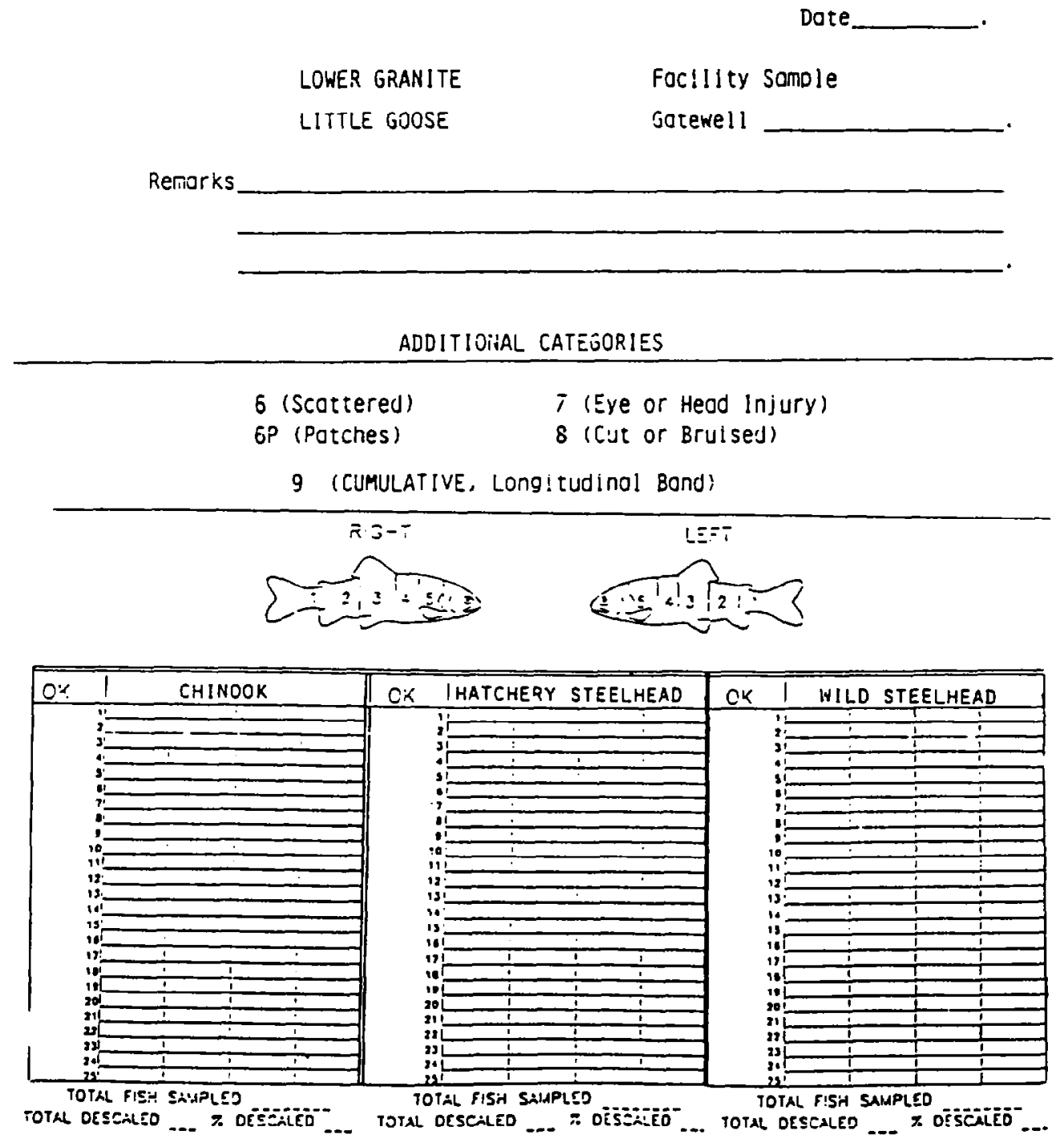

FIGURE A.1. Descaling Evaluation Data Sheet Used at Sunnyside
Canal Fish Screening Facility, Spring 1985 
I If the fish was fungoused or dead, an 8 was noted. The 8 desi gnation in the 1985 trial criteria was used to note brui sed or cut fish (Figure A. 2).

DESCALED FI SH I NCLUDE ONLY THOSE FI SH WHOSE SCALE LOSS IS $\geq 40 \%$ IN AT LEAST TVD AREAS ON ONE SI DE.

I n 1985, a nodi fied criteri on was added to the eval uation procedure (Figure A 2). The criteri on was added to i ncl ude ti sh in the descal ed category that have scal e I oss of $\geq 40 \%$ on one si de but do neet the "two area on a si de" criterion. Thi s condition uas noted by some observers at Col unbi a Ri ver dans. The criterion is descri bed as fol I ous:

If the summation of scal e l oss is $240 \%$ of two or more sections on one si de of the fish it shoul d be considered descaled and shal $\mathrm{I}$ be desi gnated separatel $\mathrm{y} \mathbf{V}^{*}$ th the number 9 .

Addi ti onal modi fi cati ons to the criteri a i ncl uded the i ncl usi on of cut and bruised fish in those desi gnated as 8' s. These fi sh should show severe si gns of trauma: i.e. bl ack or di scol ored bruises the size of a di me or cuts which show obvi ous flesh. 


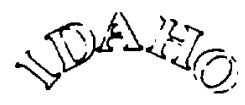

Reglon 2

1540 Warner Avenue

Lewiston. ldaho 83501

Telephone: (208) 74 3-6502

To: A I Proj ect Bi ol ogi, s'ts

From FTOT Chai rman SuF

Subj ect: J uveni I e descal i ng for nat

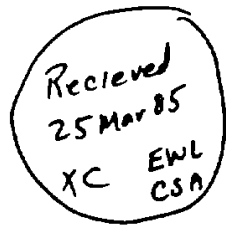

March 22. 1985

Ouring the FTOT Pre-season Metting at Walla Walla, descaling criteria uas di scussed. It was agreed that a new cirteria was needed, and that several new categori es could be added to the itens that we record ( $i n$ addition to descal i ng).

We found that there was no criteria for eval uating fish which were descal ed I ongi tudi nal I $y$ al ong the si de of the fish in the shape of a narrow band in nost cases. Hol di ng. tests conducted at McNary reveal ed that fi sh descal ed in thi s manner di ed at about the same rate as "descal ed fish".

The uorkshop group agreed that the criteria should be nodified to incl ude this group of $\mathrm{fish}$.

The fol I owi ng I anguage was adopted: I F THE SUMMATI ON OF SCALE LOSS IS EQUAL TO OR GREATER THAN 40\% OF TVD OR MORE SECTI ONS ON ONE SI DE OF THE FI SH IT SHOLD BE CONSI DERED DESCALED AND SHALL BE DESIGNATED SEPERATLY WTH THE NUMBER 9.

By desi gnating with the new \#9, these fish can be segregated so the remani ng descal ed fish can be compared to previ ous years. If you have any questions pl ease gi ve Steve Pettit or Chuck Koski a call.

In addi ti on, a NEW category of cut and brui sed ( $\$ 8)$ was i nstituted. These fi sh should show severe si gns of traum: ie.. bl ack or di scol ored brui ses the si ze of a di ne or cuts whi ch show obvi ous fl esh.

We have worked up a new descal ing form which can be used at Snake Ri ver proj ects.

cc: Bob Ral ei gh'

Don Chapman

Duane Neitzel, Battell Mw

EQUAL OPPORTUNITY EMPLOYER

FI GRE A 2. Letter From Steve Pettit, I daho Fi sh and Game, Descri bi ng the 1985 Modi fi cati ons to the Scal e LOSS Eval uati on Criteri a 


\section{REFERENCES}

Basham, L. R., M. R. Delarm, J. B. Athern, and S. W. Pettit. 1982. Fish Transportation Oversight Team Annual Report, FY 1981: Transport Operations on the Snake and Columbia Rivers. NOAA Technical Temorandum MIMFS F/NNR-2. EnvironmentaT and Technical Services Division, Northwest Regional Office, National Cceanic and Atmospheric Administration, National Martne Fishries Service, Portland, Oregon.

Park, D. L., J. R. Smith, G. M. Matthews, T. E. Ruehle, J. R. Harmon, S. Achord, B. H. Monk, and M. H. Gessel. 1982. Transportaticn Cperations and Research on the Snake and Columbia Rivers, 1981. Coastal Zone and Estuarine Studies Division, National Oceanic and Atmospheric Administration, Seattle, Washington.

RaLeigh, R., and D. Chapman. 1985. Descaling in Spring Migrants, Mid-Columbia River, 1983. Don Chapman Consultants, Inc., McCall, Idanc. 
APPENDI X B

RELEASE AND CAPTURE DATA FROM SUNNYSIDE CANAL FISH SCREENING FACILITY EVALUATION, SPRING 1985 
RELEASE AND CAPTURE DATA FROM SUNNYSIDE CANAL FISH SCREENING FACILITY EVALUATION, SPRING 1985

The data presented in Tables 1 and 2 of the main text are combined data. That is, the individual trials within a test series were combined for a single estimate. The descaled fish are considered to be dead for these estimates. The combining of dead and descaled fish was also used in the evaluation of screen performance. The data from each of the replicate tests are presented here (Tables B.1 and B.2).

TABLE B.1. Percentage of Steelhead, Salmo gairdneri, Descaled or $\mathrm{Killed}$ in Each Test at the Sunnyside Canal Fish Screening Facility, Spring 1985

\begin{tabular}{|c|c|c|c|c|c|c|}
\hline \multirow[b]{2}{*}{$\begin{array}{l}\text { RELEASE } \\
\text { SITE } \\
\end{array}$} & \multirow[b]{2}{*}{$\begin{array}{c}\text { TEST } \\
\text { REPLICATE } \\
\end{array}$} & \multicolumn{3}{|c|}{ NUMAER OF FISH } & \multirow{2}{*}{$\begin{array}{c}\text { FISH } \\
\text { DESCALED OR } \\
\text { KILLED (\$) }\end{array}$} & \multirow[b]{2}{*}{$\begin{array}{c}958 \\
\text { CONFIDENCE } \\
\text { INTERVAL } \\
\end{array}$} \\
\hline & & RELEASED & CAPTURED & $\begin{array}{l}\text { DESCALED } \\
\text { OR KILLED }\end{array}$ & & \\
\hline $\begin{array}{l}\text { PRIMARY FISH } \\
\text { RETURN PIPE }\end{array}$ & $\begin{array}{c}1 \\
2 \\
3 \\
\text { control } \\
\text { control } \\
\text { control } \\
\text { col }\end{array}$ & $\begin{array}{l}50 \\
50 \\
72 \\
50 \\
50 \\
55\end{array}$ & $\begin{array}{r}8 \\
16 \\
6 \\
8 \\
88 \\
21\end{array}$ & $\begin{array}{l}0 \\
0 \\
0 \\
0 \\
0 \\
0\end{array}$ & $\begin{array}{l}0 \\
0 \\
0 \\
0 \\
0 \\
0\end{array}$ & $\begin{array}{l}0-36.9 \\
0-20.6 \\
0-45.9 \\
0-36.0 \\
0-12.3 \\
0-16.1\end{array}$ \\
\hline $\begin{array}{l}\text { INTERMEDIATE } \\
\text { BYPASS }\end{array}$ & $\begin{array}{c}1 \\
\text { control }\end{array}$ & 275 & $\begin{array}{r}139 \\
24\end{array}$ & $\begin{array}{l}0 \\
0\end{array}$ & $\begin{array}{l}0 \\
0\end{array}$ & $\begin{array}{l}0-2.6 \\
0-14.3\end{array}$ \\
\hline $\begin{array}{l}\text { TERMINAL } \\
\text { BYPASS }\end{array}$ & $\begin{array}{c}1 \\
\text { control }\end{array}$ & 200 & $\begin{array}{r}112 \\
13\end{array}$ & $\begin{array}{l}0 \\
0\end{array}$ & $\begin{array}{l}0 \\
0\end{array}$ & $\begin{array}{l}0-3.2 \\
0-24.7\end{array}$ \\
\hline TRASH RACK & $\begin{array}{c}1 \\
\text { control }\end{array}$ & 500 & $\begin{array}{r}126 \\
19\end{array}$ & $\begin{array}{l}0 \\
0\end{array}$ & $\begin{array}{l}0 \\
0\end{array}$ & $\begin{array}{l}0-2.9 \\
0-17.7\end{array}$ \\
\hline $\begin{array}{l}\text { CANAL } \\
\text { HEADCATES }\end{array}$ & $\begin{array}{c}1 \\
\text { control }\end{array}$ & 500 & $\begin{array}{r}100 \\
20\end{array}$ & $\begin{array}{l}0 \\
0\end{array}$ & $\begin{array}{l}0 \\
0\end{array}$ & $\begin{array}{l}0-3.6 \\
0-16.8\end{array}$ \\
\hline
\end{tabular}


TABLE B.2. Percentage of Chinook Salmon, Oncurhynchus tshawytscha, Descaled or Killed in each Test at the Sunnyside Canal Fish Screening Facility, Spring 1985

\begin{tabular}{|c|c|c|c|c|c|c|}
\hline \multirow[b]{2}{*}{$\begin{array}{l}\text { RELEASE } \\
\text { SITE } \\
\end{array}$} & \multirow[b]{2}{*}{$\begin{array}{c}\text { TEST } \\
\text { REPLICATE } \\
\end{array}$} & \multicolumn{3}{|c|}{ NUMBER OF FISH } & \multirow{2}{*}{$\begin{array}{l}\text { FISH } \\
\text { DESCALED OR } \\
\text { KILLED }(z) \\
\end{array}$} & \multirow{2}{*}{$\begin{array}{c}95 \% \\
\text { CONF IDENCE } \\
\text { INTERVAL } \\
\end{array}$} \\
\hline & & RELEASED & CAPTURED & $\begin{array}{l}\text { DESCALED } \\
\text { OR KILLED }\end{array}$ & & \\
\hline $\begin{array}{l}\text { PRIMARY FISH } \\
\text { RETURN PIPE }\end{array}$ & $\begin{array}{c}1 \\
2 \\
3 \\
4 \\
5 \\
\text { control } \\
\text { control } \\
2\end{array}$ & $\begin{array}{r}100 \\
100 \\
100 \\
100 \\
100 \\
\\
50\end{array}$ & $\begin{array}{l}83 \\
64 \\
75 \\
60 \\
89 \\
36 \\
21\end{array}$ & $\begin{array}{l}0 \\
2 \\
0 \\
1 \\
0 \\
0 \\
0\end{array}$ & $\begin{array}{c}0 \\
3.1 \\
0 \\
1.7 \\
0 \\
0 \\
0\end{array}$ & $\begin{array}{c}0-4.4 \\
0.4-10.8 \\
0-4.8 \\
0-8.9 \\
0-4.1 \\
0-9.7 \\
0-16.1\end{array}$ \\
\hline $\begin{array}{l}\text { INIERMED | ATE } \\
\text { BYPASS }\end{array}$ & $\begin{array}{c}1 \\
2 \\
3 \\
4 \\
5 \\
\text { control }\end{array}$ & $\begin{array}{l}100 \\
100 \\
100 \\
100 \\
100\end{array}$ & $\begin{array}{l}82 \\
95 \\
99 \\
95 \\
97 \\
20\end{array}$ & $\begin{array}{l}2 \\
0 \\
0 \\
2 \\
0 \\
0\end{array}$ & $\begin{array}{c}2.4 \\
0 \\
0 \\
2.1 \\
0 \\
0\end{array}$ & $\begin{array}{r}0.3-8.5 \\
0-3.8 \\
0-3.7 \\
0.3-7.4 \\
0-3.7 \\
0-16.8\end{array}$ \\
\hline $\begin{array}{l}\text { TERMINAL } \\
\text { BYPASS }\end{array}$ & $\begin{array}{c}1 \\
2 \\
3 \\
4 \\
5 \\
\text { control }\end{array}$ & $\begin{array}{l}100 \\
100 \\
100 \\
100 \\
100\end{array}$ & $\begin{array}{l}98 \\
96 \\
98 \\
98 \\
86 \\
20\end{array}$ & $\begin{array}{l}2 \\
1 \\
0 \\
3 \\
1 \\
0\end{array}$ & $\begin{array}{c}2.0 \\
1.0 \\
0 \\
3.1 \\
1.2 \\
0\end{array}$ & $\begin{array}{r}0.3-7.2 \\
0-5.7 \\
0-3.7 \\
0.6-8.7 \\
0-6.3 \\
0-16.8\end{array}$ \\
\hline TRASH RACK & $\begin{array}{c}1 \\
\text { control }\end{array}$ & 1000 & $\begin{array}{r}856 \\
20\end{array}$ & $\begin{array}{r}20 \\
0\end{array}$ & $0^{2.3}$ & $\begin{array}{l}1.4-3.6 \\
0-16.8\end{array}$ \\
\hline HEADGATES & $\begin{array}{c}1 \\
2 \\
\text { control }\end{array}$ & $\begin{array}{l}1000 \\
1000\end{array}$ & $\begin{array}{r}729 \\
725 \\
32\end{array}$ & $\begin{array}{r}6 \\
21 \\
0\end{array}$ & $\begin{array}{c}0.7 \\
3.2 \\
0\end{array}$ & $\begin{array}{r}0.2-1.6 \\
2.0-4.7 \\
0-9.7\end{array}$ \\
\hline
\end{tabular}

